University of Arkansas, Fayetteville

ScholarWorks@UARK

Graduate Theses and Dissertations

8-2017

\title{
Natural air Drying and Storage of Soybean Seed and Implications on Germination Rates, Vigor, and Oil Quality
}

Zachary Young

University of Arkansas, Fayetteville

Follow this and additional works at: https://scholarworks.uark.edu/etd

Part of the Food Processing Commons

\section{Citation}

Young, Z. (2017). Natural air Drying and Storage of Soybean Seed and Implications on Germination Rates, Vigor, and Oil Quality. Graduate Theses and Dissertations Retrieved from https://scholarworks.uark.edu/ etd/2500

This Thesis is brought to you for free and open access by ScholarWorks@UARK. It has been accepted for inclusion in Graduate Theses and Dissertations by an authorized administrator of ScholarWorks@UARK. For more information, please contact scholar@uark.edu. 
Natural air Drying and Storage of Soybean Seed and Implications on Germination Rates, Vigor, and Oil Quality

A thesis submitted in partial fulfillment of the requirements for the degree of Master of Science in Food Science

by

Zachary Young

University of Arkansas - Fort Smith

Bachelor of Science in Biology, 2013

August 2017

University of Arkansas

This thesis is approved for recommendation to the Graduate Council.

Dr. Griffiths G. Atungulu

Thesis Director

Dr. Andrew Proctor

Dr. Sammy Sadaka

Committee Member

Committee Member

Dr. B. J. Bench

Committee Member 


\begin{abstract}
Recently introduced technology-comprising cables used for monitoring grain moisture content (MC) and temperature throughout the entire grain mass during drying offers a means to utilize low-temperature natural air-drying for soybean seed. From an electronic monitor and fan control standpoint, the new technology appears to be very promising for managing drying and storage conditions for soybean seed. The objectives for this study were to simulate conditions typically encountered in on-farm, in-bin drying systems and investigate impact of seed cultivar, temperature, moisture content and duration of storage on seed germination rates and vigor (electrical conductivity). In addition this research addresses the problem of establishing an accurate EMC database, across temperature and relative humidity ranges that are typically encountered during natural air, low-temperature drying of soybean seed. Overall, this study showed that seed viability could be maintained when the MC is at $13 \%$ and grain temperature within $20^{\circ} \mathrm{C}$ to $30^{\circ} \mathrm{C}$.
\end{abstract}




\section{Acknowledgements}

I would like to extend my gratitude to my advisor, Dr. Griffiths G. Atungulu of the University of Arkansas, Food Science Department, for all of his help with my thesis. His vast knowledge and guidance was key to my research and writing of this thesis. It would have been impossible to make it through my M.S. degree without his help. In addition, I would like to thank the rest of my M.S. Thesis Commitee members: Dr. Sammy Sadaka, Dr. Andy Proctor, and Dr. Bench for their insightful comments and support.

I would like to thank the Arkansas Soybean and Promotion Board for financial support. Richard Bond, Donald Dombek, Dr. Pengyin Chen and Dr. Terry Siebenmorgen for collaboration accorded during this research. I would also like to thank my colleagues in the University of Arkansas Grain Processing Program for their encouragement and support, but I would especially like to extend thanks to Mr. HouMin Zhong and Dr. Gbenga Olatunde for their valuable input during the data acquisition and analysis of this project, without them it would not have been possible to finish.

Lastly, I would like to thank my family and Ms. Sangeeta Mukhopadhyay for their moral support and for believing in me even when I did not believe in myself. 
Table of Contents

I. Introduction

II. Chapter 1: Determination of Accurate Sorption Isotherms of Soybeans for Effective InBin Drying and Storage

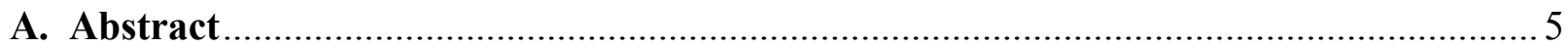

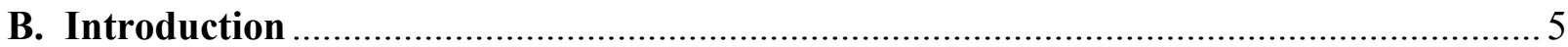

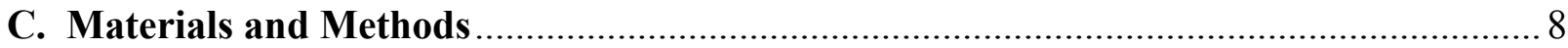

1. Soybean Sampling \& Experimental Set up............................................................. 8

2. Equilibrium Moisture Content Determination .................................................. 8

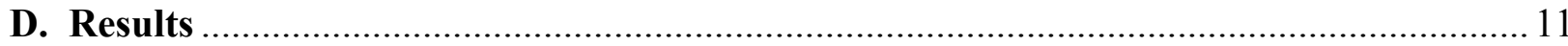

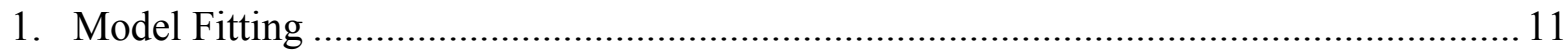

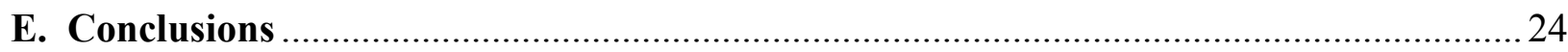

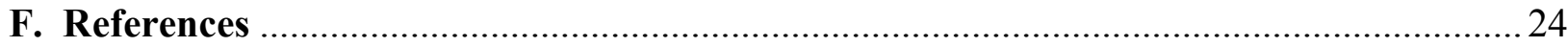

III. Chapter 2: Microbial Natural Air Drying and Storage of Soybean Seed and Implications on Germination Rates, Vigor, and Oil Quality .......................................... 25

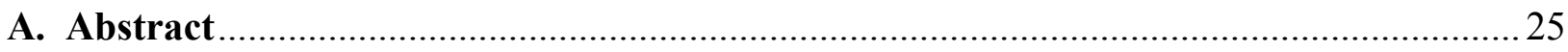

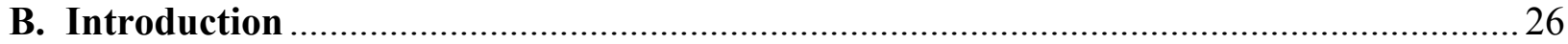

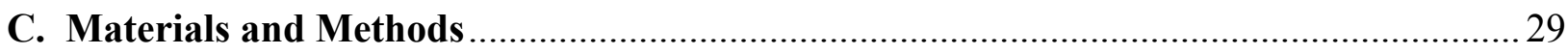

1. Soybean Sampling \& Experimental Set up.......................................................... 29

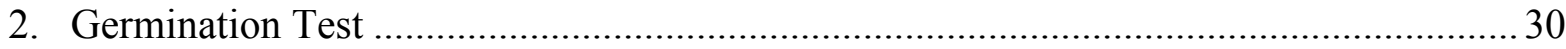

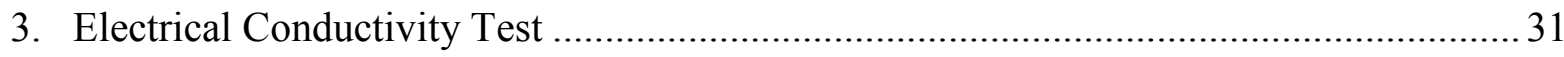

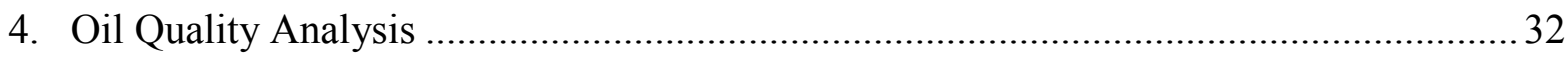

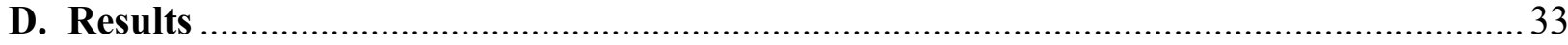

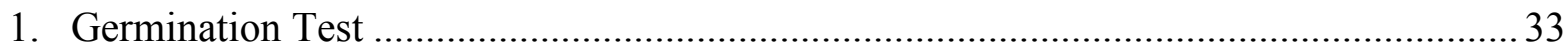

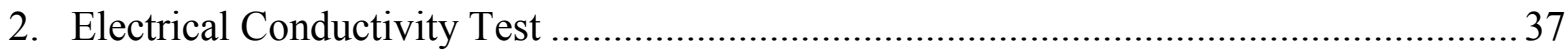

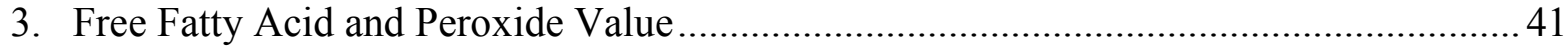

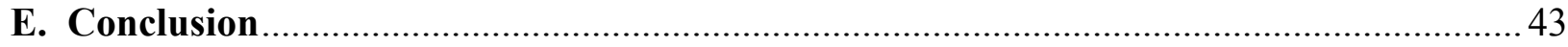

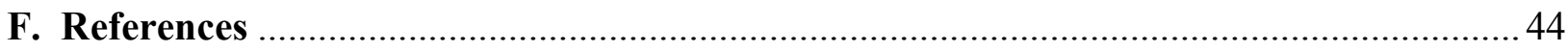

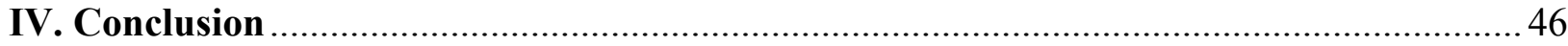




\section{Introduction}

Soybeans have the ability to absorb and loose moisture rapidly; seed viability is affected by repeated rehydration and dehydration as air condition changes during storage (Calero et al., 1981; Kpoghomou et al., 1990). The stress that the soybean seed endures during these periods of dehydration and rehydration significantly reduce the rate of successful germination as well as negatively affect overall plant vigor (Panobianco and Vieira, 2007).

Germination is defined as the sprouting of seedling or root protrusion, and it has been used as an indicator of deterioration of grains during storage. De Alencar et al. (2006) studied deterioration of soybeans stored at different $\mathrm{MCs}$, temperatures $\left(20^{\circ} \mathrm{C}, 30^{\circ} \mathrm{C}\right.$, and $\left.40^{\circ} \mathrm{C}\right)$ and relative humidities (RHs) (between 61\% and 86\%) for 180 days. The authors found that soybean stored with $\mathrm{MC}$ of $14.8 \%$ for 135 days did not germinate and there was decreased germination rate during the storage, regardless of MC and temperature. Also, Locher and Bucheli (1998) stored soybeans with initial $\mathrm{MC}$ of $9.8 \%$ and $13.8 \%$ at $30^{\circ} \mathrm{C}$ and $82 \% \mathrm{RH}$ and found a reduction in the germination percentage between 5 and 9 months of storage, where this behavior was more pronounced in seeds with greater initial MCs.

Furthermore, the stress induced by storage condition on soybeans has been identified to cause damage to cell membrane (Panobianco and Vieira, 2007). Damaged membrane causes leakage of solutes to the environment and decline in overall vigor of soybean seeds (Vieira et al., 2008). Hence, the electrical conductivity (EC) test is considered as an important tool to evaluate the seed vigor, since it indirectly assesses the cell membrane degradation degree by determining the amount of electrolytes released in the seed soaking solution. EC between 60 to $70 \mu \mathrm{S} / \mathrm{cm} / \mathrm{g}$ are considered of high vigor and between 70 to $80 \mu \mathrm{S} / \mathrm{cm} / \mathrm{g}$ are considered of medium vigor (Andric 
et al., 2007; Colete et al., 2004; Kandil et al., 2013; Vieira et al., 2001; Wain-Tassi et al., 2012a). De Alencar et al. (2011) reported deterioration of vigor in soybeans with initial MCs of 11.2\%, $12.8 \%$ and $14.8 \%$, at temperatures of $20^{\circ} \mathrm{C}, 30^{\circ} \mathrm{C}$ and $40^{\circ} \mathrm{C}$ stored for 180 days. EC increased during storage by $220 \%$ at $14.8 \% \mathrm{MC}$ and $40^{\circ} \mathrm{C}$. However, there were marginal increase in EC at $20^{\circ} \mathrm{C}$ and $30^{\circ} \mathrm{C}$ and MCs between $11.2 \%$ and $12.8 \%$. Colete et al. (2004) evaluated the electrical conductivity of three different cultivars and found they had different ECs as low ( $>100$ and < $120 \mu \mathrm{S} / \mathrm{cm} / \mathrm{g})$, medium $(81-100 \mu \mathrm{S} / \mathrm{cm} / \mathrm{g})$ and high $(<80 \mu \mathrm{S} / \mathrm{cm} / \mathrm{g})$ vigor, respectively.

Fungal attack during seed storage has been shown to affect oil quality of soybean seed. Dhingra et al. (1998) inoculated soybean seed samples with spores of Aspergillus ruber which were then stored for 20 to 140 days at $25 \pm 1{ }^{\circ} \mathrm{C}$ with $\mathrm{MC}$ varying from $11.3 \%$ to $17.7 \%$. The authors found that fungal concentration in seeds increased with storage duration, especially in those with higher MC. Free fatty acid content also increased following the pattern of fungal growth. The authors attributed the rise in free fatty acid content to an increase of $A$. ruber mass within the seed. Fungal growth did not affect fatty acids profiles or iodine index of the extracted oil. The authors concluded that free fatty acid concentration of a seed lot could be used as a sensitive indicator of seed deterioration due to storage fungi. Hepperly and Sinclair (1978) who examined the effect of Phomopsis sojae infection on soybean seed quality also noted the effect of storage fungi. They found seeds infected with $P$. sojae were smaller in size and volume, were lower in density, produced lower quality oil and flour, and had lower viability and durability than did uninfected seeds. Bhattacharya and Raha (2002) who investigated the effect of fungal infection on viability and quality deterioration of soybean seeds stored in natural conditions in Santiniketan, West Bengal, India for 1 year, also obtained similar results. The authors found an 
increase in storage fungi accompanied by a reduction in seed viability occurred in all seeds as storage proceeded.

Deterioration of soybean has been found to significantly affect the oil quality such as free fatty acids and peroxide value. Lipid oxidation is the major cause of oil and fat deterioration due to formation of hydroperoxides resulting from the reaction between oxygen and the unsaturated fatty acids. These compounds rapidly decompose to aldehydes, ketones, alcohols, hydrocarbons, esters, furans and lactones, which impart a displeasing taste and odor (Farhoosh et al., 2009). The peroxide index is a common parameter used to characterize oils and fats (O'Brien, 2004). Generally, a product with peroxide value between 1 and 5 meq kg-1 is classified by low oxidation state; that between 5 and 10 meq kg-1 at moderate oxidation and above 10 meq kg-1 is classified at high oxidation state. During the storage of grains, the lipid fraction is slowly hydrolyzed by water at high temperature or by natural lipolytic enzymes or those produced by bacteria and/or fungi, contributing to the hydrolytic rancidity of the product. Increase in the content of free fatty acids from lipids occurs by the action of lipase and phospholipase enzymes present in the soybeans or produced by the associated microflora, which contribute to the breaking of ester linkages of triglycerides (Zadernowski et al., 1999). Thus, the percentage of free fatty acids is an important indicator of quality throughout the processing of oils and fats. Vegetable oils may present relatively high contents of free fatty acids if the grains or seeds present damages due to procedures in the field or incorrect storage practices, being that high values of free fatty acids can cause excessive losses in refining. Wilson et al. (1995) claimed the refining losses between 1 and $1.5 \%$ are considered normal; however, such losses may reach $4 \%$ or more for greater levels of free fatty acids. 
De Alencar et al. (2010) investigated changes in free fatty acid (FFA) content, peroxide index of the extracted soybean oil from seed with initial MC of $11.2 \%, 12.8 \%$ and $14.8 \%$ stored at $25^{\circ} \mathrm{C}$, $30^{\circ} \mathrm{C}$ or $40^{\circ} \mathrm{C}$ at 45 -day intervals for 180 -day storage. The FFA content of oil increased with increase in storage duration. The authors attributed this to lipid hydrolysis by lipases, peroxidases and phospholipases enzymes present in grain tissues. In addition, peroxide index was found to increase independent of storage temperature. However, marginal increase was observed at $11.2 \%$ and $12.8 \%$ at $20^{\circ} \mathrm{C}$ or $30^{\circ} \mathrm{C}$. Yanagi et al. (1985) who used soybean with MC of $13.7 \%$ or $9.3 \%$ stored at $30^{\circ} \mathrm{C}$ and $80 \% \mathrm{RH}$ obtained similar results earlier. A gradual loss of carbohydrate (both soluble and insoluble) content in all the seeds were recorded as well as a loss of protein and oil content in prolonged storage with simultaneous increase in fatty acid.

The specific objectives of this study are to determine the effects of seed remaining at MC and temperature ranges encountered during in-bin drying and storage, for certain durations on germination rates and vigor of the seed. 


\section{Chapter 1}

\section{Determination of Accurate Sorption Isotherms of Soybeans for Effective In-Bin Drying and \\ Storage}

\section{A. Abstract}

Recently introduced technology-comprising cables used for monitoring grain moisture content (MC) and temperature throughout the entire grain mass during drying offers a means to utilize low-temperature natural air-drying for soybean seed. From an electronic monitor and fan control standpoint, the new technology appears to be very promising for managing drying and storage conditions for soybean seed. However, the ultimate success of this technology hinges on accurate equilibrium moisture content (EMC) data acquisition to determine fan run-time. This research addresses the problem of establishing an accurate EMC database, across temperature and relative humidity ranges that are typically encountered during natural air, low-temperature drying of soybean seed.

\section{B. Introduction}

Soybeans that are commercially grown for seed purposes are typically dried using natural air (NA) drying method in order to preserve seed quality and maintain desirable germination rate. The typical practice in Arkansas is to allow soybeans to dry to $13 \% \mathrm{MC}$ wet basis in the field before being harvested and stored in an in-bin storage system. The NA drying method involves the use of a fan(s) to force ambient air through the bed of soybeans from the bottom to the top of the bin. The temperature and relative humidity $(\mathrm{RH})$ of air that moves through the grain mass determine if the soybean grain would absorb or lose moisture. However, the ultimate success of NA drying hinges on determination of accurate EMC data to establish fan 
run time. This research focuses on addressing the problem of establishing accurate EMC data of recently grown soybean seeds. This information is critical for accurate control of the new in-bin systems.

In practice, the EMC profile of grains in bin drying systems is calculated using measured soybean temperature and $\mathrm{RH}$ of air in contact with the grain and grain-specific constants as input parameters (Ondier et al., 2011). This relationship is described by EMC sorption isotherm equations. Sorption isotherms are usually classified according to their shape as one of five different curve types: I, II, III, IV and V (Brunauer et al., 1940; Basu et al., 2006). Type I curves are convex whereas type II curves are concave. Types III, IV and V isotherms often show one or more inflection points.

Various mathematical models have been proposed in literature to describe sorption isotherms. These equations take into account the effect of temperature and $\mathrm{RH}$, such as the modified Chung- Pfost equation, modified Henderson equation (Thompson et al., 1968), modified Halsey equation, modified Oswin equation (Oswin, 1946) and Guggenheim-Anderson-de Boer (GAB) equation. The American Society of Agricultural Engineers for describing sorption isotherms (ASAE, 1995) has since adopted these models as standard equations. However, the variability of the EMC relationships between grain lots necessitates that a good model be selected or developed for each specific grain. For example, Armstrong et al. (2012) developed modified Chung-Pfost equilibrium moisture content models for seven corn cultivars and examined their prediction accuracy, as well as evaluated simplification of the experimental procedures used to develop these models based on overall model accuracy. They found that models produced from the more complicated experimental designs with $5 \mathrm{MC}$ levels had the highest standard error of estimates (SEE) averaging 0.90 and 0.82 for adsorption and desorption, respectively, while the 2- 
point model had standard errors of prediction (SEP) averaging from 0.41 and 0.39 for adsorption, and desorption, respectively. Their results show that simpler experiments can be used to create accurate models, therefore reducing the amount of work required for model development.

A similar study conducted by Sun and Byrne (1998) determined the accuracy of four commonly cited rapeseed EMC/equilibrium relative humidity (ERH) equations, i.e. modified Henderson, modified Chung-Pfost, modified Halsey and modified Oswin equations based on the residual sum of squares (RSS), SEE and mean relative deviation (MRD). Their findings showed that the modified Halsey equation was the best equation for describing the EMC/ERH isotherms of rapeseed. The authors then used the modified Halsey equation to fit the data sets after merging all the data for adsorption, desorption and the combined data set in turn. Similarly, Saravacos et al. (1986) generated water adsorption isotherms of Sultana raisins at $20^{\circ} \mathrm{C}, 25^{\circ} \mathrm{C}, 30^{\circ} \mathrm{C}$, and $35^{\circ} \mathrm{C}$. They found that EMC at water activities up to 0.70 decreased as the temperature was increased from $20^{\circ} \mathrm{C}$ to $35^{\circ} \mathrm{C}$. At higher water activities the observed $\mathrm{MC}$ increased sharply with increase in temperature, resulting in crossing of the isotherm curves. The authors attributed this behavior to the increased solubility of fruit sugars at higher temperatures. They fit the experimental data to commonly used EMC/ERH equations and found 3-parameter GAB and Halsey equations to have the best fits.

It has been theorized that the extent of hysteresis, the difference of water activity (aw) versus EMC between desorption and adsorption, is related to the nature and state of the components in a food, reflecting their potential for structural and conformational rearrangements, which in turn alter the accessibility of energetically favorable polar sites (Kapsalis, 1981; Al-Muhtaseb et al., 2004). During adsorption, proteins and carbohydrates in soybeans swell; polar sites are thus able to interact with water by forming hydrogen bonds. During drying or desorption, some solutes 
may supersaturate below their crystallization aw resulting in more water being held as aw is lowered. It has been reported that foods with high sugar content frequently exhibit this phenomenon (Bell and Labuza, 2000).

The specific objectives for this research are to determine accurate isotherms of currently produced soybeans of different chemical properties at air temperature and RH conditions typically encountered during on-farm, in-bin drying and storage of soybeans and to generate empirical constants of mathematical models for predicting the isotherms.

\section{Materials and Methods}

\section{Soybean Sampling \& Experimental Set up}

Freshly harvested soybeans samples of three different cultivars R02-6268F (High Oil, 19.25\%), R07-2000 (High Sugar, 12\%), and R09-3789 (High Protein, 38\%) were procured from commercial farms in Arkansas. The sample were allowed to dry to $10 \% \mathrm{MC}$ under room conditions $\left(25^{\circ} \mathrm{C}\right.$ and $40 \%$ to $\left.50 \% \mathrm{RH}\right)$. The samples were cleaned to remove dirt and broken seed. The MCs of each sample was determined using AM 5200 Grain Moisture Tester (PERTEN Instruments, Hägersten, Sweden). Samples were then transferred into Vapor Sorption Analyzer (VSA) (Decagon Devices Inc., Pullman, WA) for EMC determination.

\section{Equilibrium Moisture Content Determination}

The adsorption and desorption isotherms of the soybean at an initial MC of $10 \%$ were determined using a Vapor Sorption Analyzer (VSA) equipment (AquaLab Decagon Devices, Inc., Pullman, Wash) (Figure 1.1). A stainless steel cup, filled with 2 grams (g) of soybeans, was placed into the VSA chamber, which was set to target temperatures $15^{\circ} \mathrm{C}, 25^{\circ} \mathrm{C}$, or $35^{\circ} \mathrm{C}$ and 
RHs at $10 \%, 30 \%, 50 \%, 70 \%$, and $90 \%$. The VSA automatically recorded the soybean weight changes at the set conditions, and equilibrium of the sample with the air was determined when the weight difference between two successive readings of the sample weight was less than $0.01 \%$ in one hour. Using the predetermined original soybean MC, the EMCs at various RHs and temperatures were calculated for both adsorption and desorption conditions. The experiments were done in triplicate.

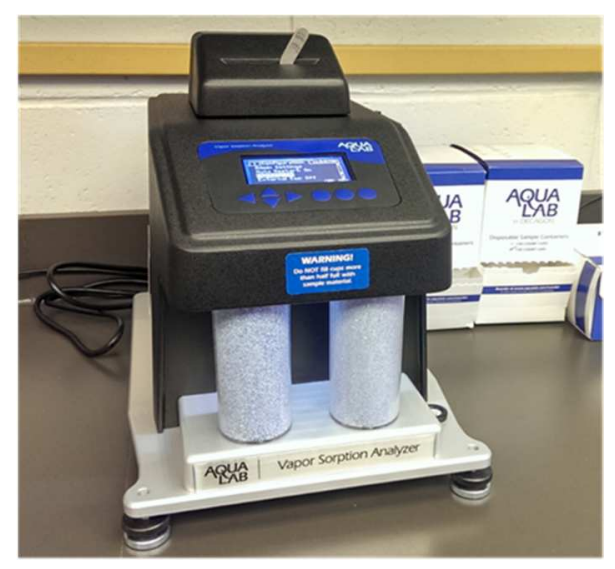

Figure 1.1: The Vapor Sorption Analyzer used to generate soybean moisture sorption isotherms.

\section{Statistical Analysis}

The MC of different soybeans cultivar during desorption and adsorption versus temperature and water activity (RH in decimal) were analyzed using nonlinear regression in JMP (JMP 12.0.0, SAS Institute, Inc., Cary, N.C.) to estimate the empirical constants (A, B, and C) of the four EMC models in table 1.1. Root mean square errors (RMSEs) between the predicted and measured EMC results were calculated and compared. 
Table 1.1: Four commonly used moisture sorption isotherm models.

Name of model Equilibrium moisture content model Water activity / ERH model

Modified Chung-Pfost $M \approx \frac{-1}{\mathrm{~B}} \ln \left[-\frac{(T+\mathrm{C})}{\mathrm{A}} \ln \left(a_{w}\right)\right] \quad a_{w} \approx \exp \left[\frac{-\mathrm{A}}{(T+\mathrm{C})} \exp (-B M)\right]$

Modified Halsey $\quad M \approx\left[\frac{-\ln \left(a_{w}\right)}{\exp (\mathrm{A}+\mathrm{B} T)}\right]^{-1 / \mathrm{C}} \quad a_{w} \approx \exp \left[-\exp (\mathrm{A}+\mathrm{B} T) M^{-C}\right]$

Modified Oswin $\quad M \approx(\mathrm{A}+\mathrm{B} T)\left[\frac{a_{w}}{1-a_{w}}\right]^{1 / \mathrm{C}} \quad a_{w} \approx \frac{1}{\left[\frac{(\mathrm{A}+\mathrm{B} T)}{M}\right]^{\mathrm{C}}+1}$

Modified GAB $\quad M \approx \frac{\mathrm{AB} \frac{C}{T} a_{w}}{\left(1-\mathrm{B} a_{w}+\left(\frac{\mathrm{C}}{T}\right) \mathrm{B} a_{w}\right)\left(1-\mathrm{B} a_{w}\right)} \quad a_{w} \approx \frac{2+\frac{C}{T}\left(\frac{\mathrm{A}}{M}-1\right)\left[\left(2+\frac{C}{T}\left(\frac{\mathrm{A}}{M}-1\right)\right)^{2}-4\left(1-\frac{\mathrm{C}}{T}\right)\right]^{\frac{1}{2}}}{2 \mathrm{~B}\left(1-\frac{\mathrm{C}}{T}\right)}$

$\dagger M$, moisture content, \% (d.b.); aw, water activity (decimal); $E R H$, Equilibrium relative humidity (decimal); $T$, temperature, $\mathrm{C}$; A, B and C, constants specific to individual equations (Aviara et al., 2004).

\section{Results \& Discussion}

\section{Model Fitting}

Greater EMCs were observed at greater RHs for the same temperature, and lesser EMCs were observed at greater temperatures for the same RH, as expected. The EMC data for soybean samples across all cultivars from the present study were comparable to EMCs obtained for the same air conditions in previous studies (ASAE, 1995). There were no consistent significant differences $(p>0.05)$ between the EMCs of high protein, high sugar, or high oil cultivars.

Empirical constants A, B, and C of the EMC equations listed in table 1.1 were estimated from the experimental data using nonlinear regression analysis. The suitability of the equations was 
evaluated using the root mean square error (RMSE). Estimates of parameters A, B, and C of the EMC equations are shown in table 1.2.

Table 1.2: Empirical constants and statistical tests for the selected models for moisture sorption isotherms of three soybean cultivars.

\begin{tabular}{|c|c|c|c|c|c|}
\hline \multirow[t]{2}{*}{ Cultivar } & \multirow[t]{2}{*}{ Constant } & \multicolumn{4}{|c|}{ Model } \\
\hline & & $\begin{array}{c}\text { Modified } \\
\text { Chung-Pfost }\end{array}$ & $\begin{array}{l}\text { Modified } \\
\text { Oswin }\end{array}$ & Modified GAB & $\begin{array}{c}\text { Modified } \\
\text { Halsey }\end{array}$ \\
\hline R09-3789 & $\mathrm{A}$ & 79.6321 & 3.2317 & 9.2643 & 4.7987 \\
\hline \multirow[t]{5}{*}{ (38\% protein) } & $\mathrm{B}$ & 0.1199 & 0.0025 & 0.0155 & 0.9322 \\
\hline & $\mathrm{C}$ & -5.7805 & 1.6357 & 1.9831 & 4750376 \\
\hline & SSE & 43.3400 & 14.6600 & 37.3850 & 8.1950 \\
\hline & MSE & 21.6750 & 1.2200 & 3.1200 & 0.6800 \\
\hline & RMSE & 4.6400 & 1.0950 & 1.7500 & 0.8200 \\
\hline R07-2000 & A & 96.4900 & 5.3909 & 14.8461 & 7.8033 \\
\hline \multirow[t]{5}{*}{ (12\% sugar) } & $\mathrm{B}$ & 0.1134 & -0.0001 & 0.0011 & 0.8601 \\
\hline & $\mathrm{C}$ & -11.6559 & 2.1623 & 2.7270 & 2618100 \\
\hline & SSE & 52.6050 & 47.3650 & 99.4100 & 44.2300 \\
\hline & MSE & 17.5350 & 3.9450 & 8.2850 & 3.6900 \\
\hline & RMSE & 4.1750 & 1.9750 & 2.8650 & 1.9200 \\
\hline $\mathrm{R} 02-6268 \mathrm{~F}$ & $\mathrm{~A}$ & 113.4991 & 3.7925 & 10.3970 & 5.6029 \\
\hline \multirow[t]{5}{*}{ (19.25\% oil) } & $\mathrm{B}$ & 0.1184 & 0.0046 & 0.0298 & 0.9097 \\
\hline & $\mathrm{C}$ & 1.2715 & 1.7993 & 2.2092 & 2378498 \\
\hline & SSE & 51.8100 & 26.0200 & 58.3050 & 19.4050 \\
\hline & MSE & 20.9750 & 2.1650 & 4.8600 & 1.6200 \\
\hline & RMSE & 4.5750 & 1.4750 & 2.2050 & 1.2700 \\
\hline
\end{tabular}

Based on minimizing RMSE, for temperatures ranging from $15^{\circ} \mathrm{C}$ to $35^{\circ} \mathrm{C}$ and $\mathrm{RHs}$ from $10 \%$ to 90\%, the modified Halsey equation was the best model for describing EMC data of soybean samples, followed by the modified Oswin, modified GAB, and modified Chung-Pfost equations. It should be noted that the modified Oswin and modified Halsey equations gave nearly identical RMSE values. Several studies have reported similar observations (Basu et al, 2006). The modified Chung-Pfost model describes the data well at $35^{\circ} \mathrm{C}$ but become less accurate at low 
temperatures and RHs. These models can be applied within the range of water activities $10 \%$ to $90 \%$, which corresponds to normal commercial storage conditions for soybean seed.

Tables 1.3, 1.4, 1.5, 1.6, 1.7 and 1.8 list the number of experimental points extracted from EMC data of soybean cultivars grown in Arkansas. The large number of the data sub-sets available enabled a detailed comparison of the four selected equations. Generally, the fitting of individual data sets for a single variety and a sorption process is a more sensitive test of the equations than the fitting of the entire data set including different varieties with a large amount of scatter. The predicted EMC of the four isotherm equations are listed in tables 1.3, 1.4, 1.5, 1.6, 1.7 and 1.8, together with mean relative deviation (MRD) which determined the performance of each equation. The most appropriate equation for predicting soybean EMC was selected based on the average values over data sub-sets of error parameters (MRD) are compared by means of the results listed in tables $1.3,1.4,1.5,1.6,1.7$ and 1.8 .

The comparison of the combined data curves predicted by the fitted isotherm equations are given in figures 1.2, 1.3, and 1.4. The fitted equations for adsorption and desorption can be used for describing rewetting and drying processes, respectively. Drying is a common practice in soybean storage and this represents the need for the desorption isotherm equation; the rewetting process does occur during storage, especially in the region near the ventilation inlet. Ventilation is a very important task in some states such as Arkansas where soybean is stored in bins without drying after being harvested. Soybean stored in Arkansas is at risk and the risk will increase if the grain is stored up to summer when grain surface warming will take place. Therefore, description of the water activity during adsorption is needed in order to accurately control the moisture content in Arkansas. The combined isotherms shown in figures 1.2, 1.3, and 1.4 also indicate the existence of hysteresis, with the desorption curve lying clearly above the adsorption curve. The 
comparison of other isotherms generated for this study showed that with the increase in temperature, the effect of hysteresis decreases, and the curves are brought closer together. Hysteresis is a complicated phenomenon and is still not fully understood and the explanation is not clear. The combined curve lies between the adsorption and desorption curves. The data used for fitting are the combination of both adsorption, and desorption data. 

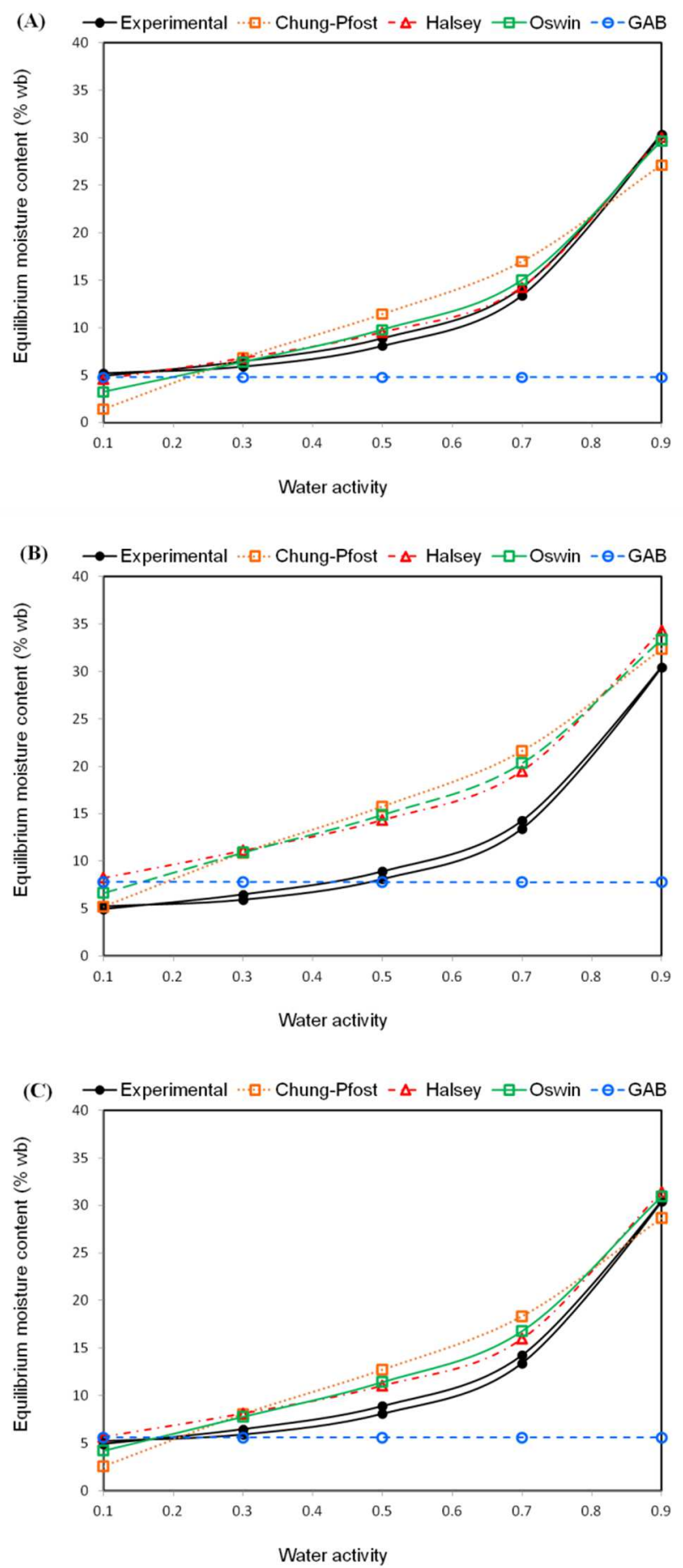

Fig. 1.2. Comparison of experimental equilibrium moisture content (EMC) with model predicted EMC for (A) high protein, (B) high sugar, and (C) high oil soybean cultivars; model predictions are shown for all cultivars at $35^{\circ} \mathrm{C}$. 

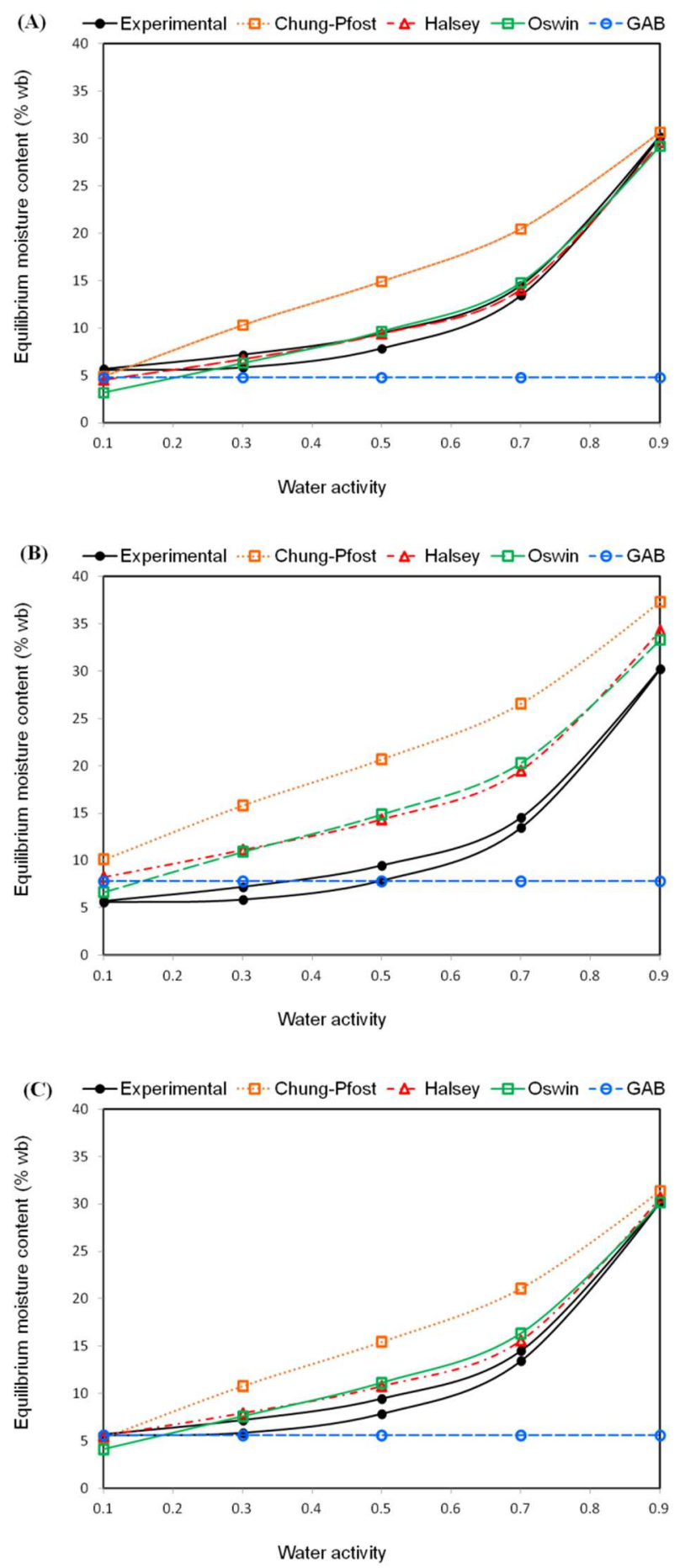

Fig. 1.3. Comparison of experimental equilibrium moisture content (EMC) with model predicted EMC for (A) high protein, (B) high sugar, and (C) high oil soybean cultivars; model predictions are shown for all cultivars at $25^{\circ} \mathrm{C}$. 

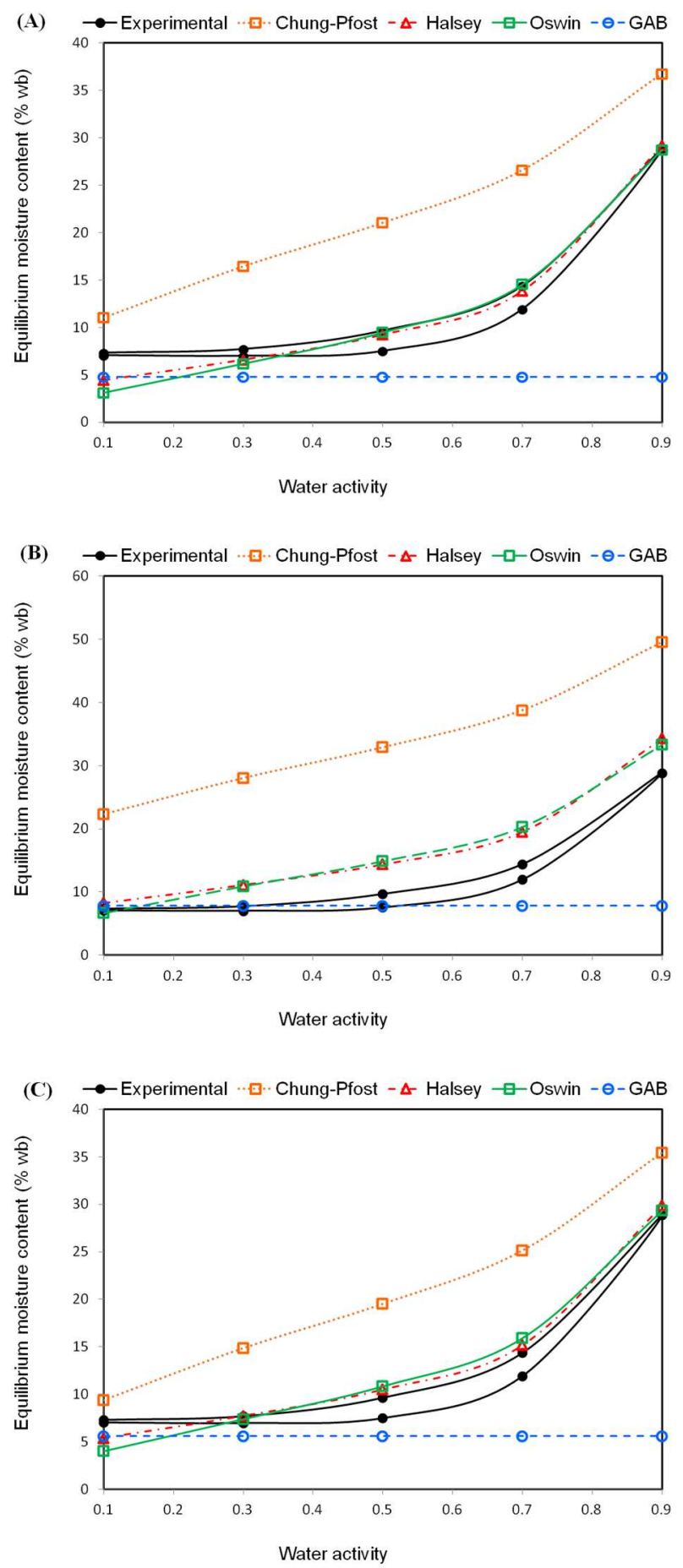

Fig. 1.4. Comparison of experimental equilibrium moisture content (EMC) with model predicted EMC for (A) high protein, (B) high sugar, and (C) high oil soybean cultivars; model predictions are shown for all cultivars at $15^{\circ} \mathrm{C}$. 
Table 1.3: Experimental equilibrium moisture content (EMC) compared with model predicted EMC during adsorption for three soybean cultivars at $15^{\circ} \mathrm{C}$.

\begin{tabular}{lllllll}
\hline Cultivar & $\begin{array}{l}\text { Water } \\
\text { activity }\end{array}$ & $\begin{array}{l}\text { Expt. } \\
\text { EMC }\end{array}$ & \multicolumn{4}{c}{ Model prediction } \\
& & & MCP & MH & MO & MGAB \\
\cline { 2 - 7 } & 0.1 & 7.67 & 11.0 & 4.4 & 3.1 & 4.7985 \\
R09-3789 & 0.3 & 7.72 & 16.4 & 6.6 & 6.2 & 4.7983 \\
(high & 0.5 & 8.03 & 21.1 & 9.2 & 9.5 & 4.7980 \\
protein) & 0.7 & 9.83 & 26.6 & 13.8 & 14.6 & 4.7977 \\
& 0.9 & 29.42 & 36.8 & 29.2 & 28.8 & 4.7974 \\
& & & & & & \\
R07-2000 & 0.1 & 7.07 & 22.3 & 8.2 & 6.6 & 7.8028 \\
(high sugar) & 0.5 & 7.01 & 28.0 & 11.1 & 10.9 & 7.8020 \\
& 0.7 & 11.95 & 32.9 & 14.3 & 14.9 & 7.8012 \\
& 0.9 & 28.84 & 49.5 & 34.3 & 33.3 & 7.7997 \\
& & & & & & \\
R02-6268F & 0.3 & 7.34 & 14.8 & 7.7 & 7.4 & 5.6019 \\
(high oil) & 0.5 & 7.86 & 19.5 & 10.5 & 10.8 & 5.6012 \\
& 0.7 & 11.89 & 25.1 & 15.2 & 15.9 & 5.6006 \\
& 0.9 & 29.43 & 35.4 & 29.9 & 29.3 & 5.6000 \\
\hline
\end{tabular}

Expt. Represents experimental; MCP, MH, MO, MGAB represent Modified Chung-Pfost, Modified Halsey, Modified Oswin, and Modified Guggenheim-Anderson-de Boer (GAB) respectively. 
Table 1.4: Experimental equilibrium moisture content (EMC) compared with model predicted EMC during desorption for the indicated soybean cultivars at $15^{\circ} \mathrm{C}$.

\begin{tabular}{lllllll}
\hline Cultivar & $\begin{array}{l}\text { Water } \\
\text { activity }\end{array}$ & $\begin{array}{l}\text { Expt. } \\
\text { EMC }\end{array}$ & \multicolumn{3}{c}{ Model prediction } \\
& & & MCP & MH & MO & MGAB \\
\cline { 2 - 7 } & 0.9 & 29.42 & 36.8 & 29.2 & 28.8 & 4.7974 \\
R09-3789 & 0.7 & 17.6 & 26.6 & 13.8 & 14.6 & 4.7977 \\
(high protein) & 0.5 & 14.47 & 21.1 & 9.2 & 9.5 & 4.7980 \\
& 0.3 & 13.02 & 16.4 & 6.6 & 6.2 & 4.7983 \\
& 0.1 & 10.19 & 11.0 & 4.4 & 3.1 & 4.7985 \\
& & & & & & \\
R07-2000 & 0.9 & 28.84 & 49.5 & 34.3 & 33.3 & 7.7997 \\
(high sugar) & 0.5 & 14.39 & 38.8 & 19.5 & 20.3 & 7.8005 \\
& 0.3 & 7.72 & 28.0 & 11.1 & 10.9 & 7.8020 \\
& 0.1 & 7.34 & 22.3 & 8.2 & 6.6 & 7.8028 \\
& & & & & & \\
R02-6268F & 0.9 & 29.43 & 35.4 & 29.9 & 29.3 & 5.6000 \\
(high oil) & 0.5 & 15.51 & 25.1 & 15.2 & 15.9 & 5.6006 \\
& 0.3 & 9.61 & 14.8 & 7.7 & 7.4 & 5.6019 \\
& 0.1 & 8.63 & 9.4 & 5.4 & 4.0 & 5.6025 \\
\hline Represents
\end{tabular}

Expt. Represents experimental; MCP, MH, MO, MGAB represent Modified Chung-Pfost, Modified Halsey, Modified Oswin, and Modified Guggenheim-Anderson-de Boer (GAB) respectively. 
Table 1.5: Experimental equilibrium moisture content (EMC) compared with model predicted EMC during adsorption for three soybean cultivars at $25^{\circ} \mathrm{C}$.

\begin{tabular}{lllllll}
\hline Cultivar & $\begin{array}{l}\text { Water } \\
\text { activity }\end{array}$ & $\begin{array}{l}\text { Expt. } \\
\text { EMC }\end{array}$ & \multicolumn{4}{c}{ Model prediction } \\
& & & MCP & \multicolumn{1}{c}{ MH } & MO & MGAB \\
\cline { 2 - 7 } & 0.1 & 5.58 & 4.9 & 4.5 & 3.2 & 4.7985 \\
R09-3789 & 0.3 & 5.85 & 10.3 & 6.7 & 6.3 & 4.7980 \\
(high & 0.5 & 7.86 & 14.9 & 9.4 & 9.7 & 4.7975 \\
protein) & 0.7 & 13.42 & 20.5 & 14.1 & 14.8 & 4.7971 \\
& 0.9 & 30.2 & 30.6 & 29.6 & 29.2 & 4.7966 \\
& & & & & & \\
R07-2000 & 0.1 & 7.61 & 10.1 & 8.2 & 6.6 & 7.8025 \\
(high sugar) & 0.5 & 7.59 & 15.8 & 11.1 & 10.9 & 7.8012 \\
& 0.7 & 13.56 & 26.5 & 19.5 & 20.3 & 7.7987 \\
& 0.9 & 31.94 & 37.3 & 34.3 & 33.3 & 7.7974 \\
& & & & & & \\
R02-6268F & 0.3 & 7.44 & 10.8 & 7.9 & 7.6 & 5.6012 \\
(high oil) & 0.5 & 8.94 & 15.5 & 10.8 & 11.1 & 5.6002 \\
& 0.7 & 14.2 & 21.1 & 15.6 & 16.3 & 5.5991 \\
& 0.9 & 31.49 & 31.4 & 30.6 & 30.1 & 5.5980 \\
\hline
\end{tabular}

Expt. Represents experimental; MCP, MH, MO, MGAB represent Modified Chung-Pfost, Modified Halsey, Modified Oswin, and Modified Guggenheim-Anderson-de Boer (GAB) respectively. 
Table 1.6: Experimental equilibrium moisture content (EMC) compared with model predicted EMC during desorption for the indicated soybean cultivars at $25^{\circ} \mathrm{C}$.

\begin{tabular}{lllllll}
\hline Cultivar & $\begin{array}{l}\text { Water } \\
\text { activity }\end{array}$ & $\begin{array}{l}\text { Expt. } \\
\text { EMC }\end{array}$ & \multicolumn{4}{c}{ Model prediction } \\
& & & MCP & MH & MO & MGAB \\
\cline { 2 - 7 } & 0.9 & 30.2 & 30.6 & 29.6 & 29.2 & 4.7966 \\
R09-3789 & 0.7 & 14.49 & 20.5 & 14.1 & 14.8 & 4.7971 \\
(high & 0.5 & 9.46 & 14.9 & 9.4 & 9.7 & 4.7975 \\
protein) & 0.3 & 7.2 & 10.3 & 6.7 & 6.3 & 4.7980 \\
& 0.1 & 5.7 & 4.9 & 4.5 & 3.2 & 4.7985 \\
& & & & & & \\
R07-2000 & 0.9 & 31.94 & 37.3 & 34.3 & 33.3 & 7.7974 \\
(high sugar) & 0.5 & 16.1 & 26.5 & 19.5 & 20.3 & 7.7987 \\
& 0.3 & 9.17 & 15.8 & 11.1 & 10.9 & 7.8012 \\
& 0.1 & 7.84 & 10.1 & 8.2 & 6.6 & 7.8025 \\
& & & & & & \\
R02-6268F & 0.7 & 15.84 & 21.1 & 15.6 & 16.3 & 5.5991 \\
(high oil) & 0.5 & 10.66 & 15.5 & 10.8 & 11.1 & 5.6002 \\
& 0.3 & 8.23 & 10.8 & 7.9 & 7.6 & 5.6012 \\
& 0.1 & 7.43 & 5.3 & 5.5 & 4.1 & 5.6023 \\
\hline
\end{tabular}

Expt. Represents experimental; MCP, MH, MO, MGAB represent Modified Chung-Pfost, Modified Halsey, Modified Oswin, and Modified Guggenheim-Anderson-de Boer (GAB) respectively. 
Table 1.7: Experimental equilibrium moisture content (EMC) compared with model predicted EMC during adsorption for three soybean cultivars at $35^{\circ} \mathrm{C}$.

\begin{tabular}{lllllll}
\hline Cultivar & $\begin{array}{l}\text { Water } \\
\text { activity }\end{array}$ & $\begin{array}{l}\text { Expt. } \\
\text { EMC }\end{array}$ & \multicolumn{4}{c}{ Model prediction } \\
& & & MCP & \multicolumn{1}{c}{ MH } & MO & MGAB \\
\cline { 2 - 7 } & 0.1 & 6.75 & 1.4 & 4.6 & 3.2 & 4.7984 \\
R09-3789 & 0.3 & 6.97 & 6.8 & 6.8 & 6.4 & 4.7977 \\
(high & 0.5 & 7.81 & 11.4 & 9.5 & 9.8 & 4.7971 \\
protein) & 0.7 & 11.49 & 17.0 & 14.3 & 15.0 & 4.7964 \\
& 0.9 & 30.19 & 27.1 & 30.1 & 29.7 & 4.7958 \\
& & & & & & \\
R07-2000 & 0.1 & 5.85 & 5.2 & 8.2 & 6.6 & 7.8023 \\
(high sugar) & 0.5 & 8.67 & 15.8 & 14.3 & 14.9 & 7.7987 \\
& 0.7 & 14.39 & 21.6 & 19.5 & 20.3 & 7.7969 \\
& 0.9 & 32.57 & 32.4 & 34.2 & 33.3 & 7.7951 \\
& & & & & & \\
R02-6268F & 0.3 & 5.91 & 8.1 & 8.1 & 7.8 & 5.6006 \\
(high oil) & 0.5 & 8.09 & 12.7 & 11.0 & 11.4 & 5.5991 \\
& 0.7 & 15.4 & 18.3 & 16.0 & 16.8 & 5.5976 \\
& 0.9 & 32.45 & 28.6 & 31.4 & 30.9 & 5.5961 \\
\hline
\end{tabular}

Expt. Represents experimental; MCP, MH, MO, MGAB represent Modified Chung-Pfost, Modified Halsey, Modified Oswin, and Modified Guggenheim-Anderson-de Boer (GAB) respectively. 
Table 1.8: Experimental equilibrium moisture content (EMC) compared with model predicted EMC during desorption for the indicated soybean cultivars at $35^{\circ} \mathrm{C}$.

\begin{tabular}{lllllll}
\hline Cultivar & $\begin{array}{l}\text { Water } \\
\text { activity }\end{array}$ & $\begin{array}{l}\text { Expt. } \\
\text { EMC }\end{array}$ & \multicolumn{4}{c}{ Model prediction } \\
& & & MCP & MH & MO & MGAB \\
\cline { 2 - 7 } & 0.9 & 30.19 & 27.1 & 30.1 & 29.7 & 4.7958 \\
R09-3789 & 0.7 & 15.12 & 17.0 & 14.3 & 15.0 & 4.7964 \\
(high & 0.5 & 9.87 & 11.4 & 9.5 & 9.8 & 4.7971 \\
protein) & 0.3 & 7.83 & 6.8 & 6.8 & 6.4 & 4.7977 \\
& 0.1 & 7.06 & 1.4 & 4.6 & 3.2 & 4.7984 \\
& & & & & & \\
R07-2000 & 0.9 & 32.57 & 32.4 & 34.2 & 33.3 & 7.7951 \\
(high sugar) & 0.7 & 15.21 & 21.6 & 19.5 & 20.3 & 7.7969 \\
& 0.3 & 6.8 & 15.8 & 14.3 & 14.9 & 7.7987 \\
& 0.1 & 5.52 & 10.9 & 11.1 & 10.9 & 7.8005 \\
& & & & 8.2 & 6.6 & 7.8023 \\
& 0.9 & 32.45 & 28.6 & 31.4 & 30.9 & 5.5961 \\
R02-6268F & 0.7 & 16.24 & 18.3 & 16.0 & 16.8 & 5.5976 \\
(high oil) & 0.5 & 8.9 & 12.7 & 11.0 & 11.4 & 5.5991 \\
& 0.3 & 6.47 & 8.1 & 8.1 & 7.8 & 5.6006 \\
& 0.1 & 4.93 & 2.6 & 5.7 & 4.2 & 5.6021 \\
\hline
\end{tabular}

Expt. Represents experimental; MCP, MH, MO, MGAB represent Modified Chung-Pfost, Modified Halsey, Modified Oswin, and Modified Guggenheim-Anderson-de Boer (GAB) respectively. 


\section{E. Conclusions}

In summary, this study finds the modified Halsey and Oswin equations as the most appropriate equations for describing soybean EMC/ERH sorption isotherms based on their ability to fit multiple data sets. The modified GAB equation and the modified Chung-Pfost equation are less suitable for describing the EMC/ERH sorption isotherms of soybean seed. The fitted equations presented here for adsorption and desorption with the combined data provide a useful basis for future work on drying and storage of soybean seed.

\section{F. References}

Al-Muhtaseb, A.H., McMinn, W.A.M., Magee, T.R.A., 2004. Water Sorption Isotherms of Starch Powders. Part 1: mathematical description of experimental data. Journal of Food Engineering 6, 297-307.

Armstrong, P. R., Casada, M. E., Lawrence, J., 2012. Development of Equilibrium Moisture Relationships for Storage Moisture Monitoring of Corn. Applied Engineering in Agriculture Vol. 28(5), 677-683

ASAE, 1995. Moisture Relationship of Plant-based Agricultural Products. ASAE Standard D245.5. St. Joseph, Michigan.

Basu, S., Shivhare, U.S., Mujumdar, A.S., 2006. Models for sorption isotherms for foods: a review. Drying Technology 24, 917-930.

Bell, L.N., Labuza, T.P., 2000. Practical Aspects of Moisture Sorption Isotherm Measurement and Use, 2nd ed. AACC Egan Press, Egan, MN, 22-26.

Brunauer, S., Deming, L.S., Deming, W.E., Teller, E., 1940. On a theory of the Van der Waals Adsorption of Gases. Journal of the American Chemical Society 62, 1723-1732.

Da-Wen Sun, C. Byrne, 1998. Selection of EMC/ERH Isotherm Equations for Rapeseed. Journal of Agricultural Engineering Research Volume 69 (4), 307-315.

Kapsalis, J.G., 1981. Moisture Sorption Hysteresis. In: Rockland, L.B.,Stewart, G.F. (Eds.), Water Activity: Influences on Food Quality. Academic Press, New York, 143-177. 
Ondier, G. O., Siebenmorgen, T. J., Bautista, R. C., and Mauromoustakos, A., 2011. Equilibrium Moisture Contents of Pureline, Hybrid, and Parboiled Rice. Trans. ASABE 54(3): 1007-1013.

Oswin, C.R., 1946. The kinetics of Package Life. III. Isotherm. Journal of the Society of Chemical Industry 65, 419-421.

Saravacos, G. D., D. A. Tsiourvas, E. Tsami, 1986. Effect of Temperature on the Water Adsorption Isotherms of Sultana Raisins. Journal of Food Science, Volume 51 (2), 381-383.

Thompson, T.L., Peart, R.M., Foster, G.H., 1968. Mathematical simulation of corn drying: a new model. Transactions of the American Society of Agricultural Engineers 11, 582-586. 


\section{Chapter 2}

\section{Natural Air Drying and Storage of Soybean Seed and Implications on Germination Rates, Vigor, and Oil Quality}

\section{A. Abstract}

Recently introduced in-bin drying and storage systems comprises cables used to monitor grain moisture content and temperature throughout the entire grain bin mass and offers a means to utilize natural air-drying for soybean seed. However, a firm understanding of the implications of using these new systems on seed quality is yet to be determined. The objectives for this study were to simulate conditions typically encountered in on-farm, in-bin drying systems and investigate impact of seed cultivar, temperature, moisture content and duration of storage on seed germination rates and vigor (electrical conductivity). This study used soybean of different cultivars (ES5650, ES5507, and ES5542) that were harvested at moisture contents (MCs) 10\%, $13 \%$ and $16 \%$ for each of the cultivars. The soybean seeds were placed in a relative humidity chamber for 2 months at typical bin drying temperatures of $20^{\circ} \mathrm{C}, 30^{\circ} \mathrm{C}$, and $40^{\circ} \mathrm{C}$ with relative humidities between $20 \%$ to $80 \%$. Samples from each of these treatments were collected after 0 , $5,10,20,30,40$, and 60 days of storage for germination, vigor (electrical conductivity), and oil quality tests which were carried out using International Seed Testing Agency (ISTA) standard procedures. Results showed the ES5542 cultivar seed germination potential dropped from 98\% at day 0 to $27 \%$ at day 60 as temperature increased from $20^{\circ} \mathrm{C}$ to $40^{\circ} \mathrm{C}$. The electrical conductivity increased from $280 \mu / \mathrm{s}$ to $1017 \mu / \mathrm{s}$ with increase in storage duration from day 0 to day 60 ( $\mathrm{p}$ $<0.05)$. Cultivar ES5507 had the least change in germination $(98 \%-63 \%)$ and electrical conductivity $(280 \mu / \mathrm{s}-685 \mu / \mathrm{s})$ within 60 days of the test at $20^{\circ} \mathrm{C}$. In addition, as MC increased from $13 \%$ to $16 \%$, the germination rate reduced by $67 \%, 20 \%$, and $17 \%$ for ES5507, ES5542, 
and ES5650 cultivar, respectively, at $20^{\circ} \mathrm{C}$. Overall, this study showed that seed viability could be maintained when the $\mathrm{MC}$ is at $13 \%$ and grain temperature within $20^{\circ} \mathrm{C}$ to $30^{\circ} \mathrm{C}$.

\section{B. Introduction}

Soybeans have the ability to absorb and loose moisture rapidly; seed viability is affected by repeated rehydration and dehydration as air condition changes during storage (Calero et al., 1981; Kpoghomou et al., 1990). The stress that the soybean seed endures during these periods of dehydration and rehydration significantly reduce the rate of successful germination as well as negatively affect overall plant vigor (Panobianco and Vieira, 2007).

Germination is defined as the sprouting of seedling or root protrusion, and it has been used as an indicator of deterioration of grains during storage. De Alencar et al. (2006) studied deterioration of soybeans stored at different $\mathrm{MCs}$, temperatures $\left(20^{\circ} \mathrm{C}, 30^{\circ} \mathrm{C}\right.$, and $\left.40^{\circ} \mathrm{C}\right)$ and relative humidities (RHs) (between $61 \%$ and $86 \%$ ) for 180 days. The authors found that soybean stored with $\mathrm{MC}$ of $14.8 \%$ for 135 days did not germinate and there was decreased germination rate during the storage, regardless of MC and temperature. Also, Locher and Bucheli (1998) stored soybeans with initial $\mathrm{MC}$ of $9.8 \%$ and $13.8 \%$ at $30^{\circ} \mathrm{C}$ and $82 \% \mathrm{RH}$ and found a reduction in the germination percentage between 5 and 9 months of storage, where this behavior was more pronounced in seeds with greater initial MCs.

Furthermore, the stress induced by storage condition on soybeans has been identified to cause damage to cell membrane (Panobianco and Vieira, 2007). Damaged membrane causes leakage of solutes to the environment and decline in overall vigor of soybean seeds (Vieira et al., 2008). Hence, the electrical conductivity (EC) test is considered as an important tool to evaluate the seed vigor, since it indirectly assesses the cell membrane degradation degree by determining the 
amount of electrolytes released in the seed soaking solution. EC between 60 to $70 \mu \mathrm{S} / \mathrm{cm} / \mathrm{g}$ are considered of high vigor and between 70 to $80 \mu \mathrm{S} / \mathrm{cm} / \mathrm{g}$ are considered of medium vigor (Andric et al., 2007; Colete et al., 2004; Kandil et al., 2013; Vieira et al., 2001; Wain-Tassi et al., 2012a). De Alencar et al. (2011) reported deterioration of vigor in soybeans with initial MCs of $11.2 \%$, $12.8 \%$ and $14.8 \%$, at temperatures of $20^{\circ} \mathrm{C}, 30^{\circ} \mathrm{C}$ and $40^{\circ} \mathrm{C}$ stored for 180 days. EC increased during storage by $220 \%$ at $14.8 \% \mathrm{MC}$ and $40^{\circ} \mathrm{C}$. However, there were marginal increase in $\mathrm{EC}$ at $20^{\circ} \mathrm{C}$ and $30^{\circ} \mathrm{C}$ and $\mathrm{MCs}$ between $11.2 \%$ and $12.8 \%$. Colete et al. (2004) evaluated the electrical conductivity of three different cultivars and found they had different ECs as low $(>100$ and $<$ $120 \mu \mathrm{S} / \mathrm{cm} / \mathrm{g})$, medium $(81-100 \mu \mathrm{S} / \mathrm{cm} / \mathrm{g})$ and high $(<80 \mu \mathrm{S} / \mathrm{cm} / \mathrm{g})$ vigor, respectively.

Fungal attack during seed storage has been shown to affect oil quality of soybean seed. Dhingra et al. (1998) inoculated soybean seed samples with spores of Aspergillus ruber which were then stored for 20 to 140 days at $25 \pm 1{ }^{\circ} \mathrm{C}$ with $\mathrm{MC}$ varying from $11.3 \%$ to $17.7 \%$. The authors found that fungal concentration in seeds increased with storage duration, especially in those with higher MC. Free fatty acid content also increased following the pattern of fungal growth. The authors attributed the rise in free fatty acid content to an increase of $A$. ruber mass within the seed. Fungal growth did not affect fatty acids profiles or iodine index of the extracted oil. The authors concluded that free fatty acid concentration of a seed lot could be used as a sensitive indicator of seed deterioration due to storage fungi. Hepperly and Sinclair (1978) who examined the effect of Phomopsis sojae infection on soybean seed quality also noted the effect of storage fungi. They found seeds infected with $P$. sojae were smaller in size and volume, were lower in density, produced lower quality oil and flour, and had lower viability and durability than did uninfected seeds. Bhattacharya and Raha (2002) who investigated the effect of fungal infection on viability and quality deterioration of soybean seeds stored in natural conditions in 
Santiniketan, West Bengal, India for 1 year, also obtained similar results. The authors found an increase in storage fungi accompanied by a reduction in seed viability occurred in all seeds as storage proceeded.

Deterioration of soybean has been found to significantly affect the oil quality such as free fatty acids and peroxide value. Lipid oxidation is the major cause of oil and fat deterioration due to formation of hydroperoxides resulting from the reaction between oxygen and the unsaturated fatty acids. These compounds rapidly decompose to aldehydes, ketones, alcohols, hydrocarbons, esters, furans and lactones, which impart a displeasing taste and odor (Farhoosh et al., 2009). The peroxide index is a common parameter used to characterize oils and fats ( $\left.\mathrm{O}^{\prime} \mathrm{Brien}, 2004\right)$. Generally, a product with peroxide value between 1 and 5 meq kg-1 is classified by low oxidation state; that between 5 and 10 meq kg-1 at moderate oxidation and above 10 meq kg-1 is classified at high oxidation state. During the storage of grains, the lipid fraction is slowly hydrolyzed by water at high temperature or by natural lipolytic enzymes or those produced by bacteria and/or fungi, contributing to the hydrolytic rancidity of the product. Increase in the content of free fatty acids from lipids occurs by the action of lipase and phospholipase enzymes present in the soybeans or produced by the associated microflora, which contribute to the breaking of ester linkages of triglycerides (Zadernowski et al., 1999). Thus, the percentage of free fatty acids is an important indicator of quality throughout the processing of oils and fats. Vegetable oils may present relatively high contents of free fatty acids if the grains or seeds present damages due to procedures in the field or incorrect storage practices, being that high values of free fatty acids can cause excessive losses in refining. Wilson et al. (1995) claimed the refining losses between 1 and $1.5 \%$ are considered normal; however, such losses may reach $4 \%$ or more for greater levels of free fatty acids. 
De Alencar et al. (2010) investigated changes in free fatty acid (FFA) content, peroxide index of the extracted soybean oil from seed with initial MC of $11.2 \%, 12.8 \%$ and $14.8 \%$ stored at $25^{\circ} \mathrm{C}$, $30^{\circ} \mathrm{C}$ or $40^{\circ} \mathrm{C}$ at 45 -day intervals for 180 -day storage. The FFA content of oil increased with increase in storage duration. The authors attributed this to lipid hydrolysis by lipases, peroxidases and phospholipases enzymes present in grain tissues. In addition, peroxide index was found to increase independent of storage temperature. However, marginal increase was observed at $11.2 \%$ and $12.8 \%$ at $20^{\circ} \mathrm{C}$ or $30^{\circ} \mathrm{C}$. Yanagi et al. (1985) who used soybean with MC of $13.7 \%$ or $9.3 \%$ stored at $30^{\circ} \mathrm{C}$ and $80 \% \mathrm{RH}$ obtained similar results earlier. A gradual loss of carbohydrate (both soluble and insoluble) content in all the seeds were recorded as well as a loss of protein and oil content in prolonged storage with simultaneous increase in fatty acid.

The specific objectives of this study are to determine the effects of seed remaining at MC and temperature ranges encountered during in-bin drying and storage, for certain durations on germination rates and vigor of the seed.

\section{Materials \& Methods}

\section{Soybean Sampling \& Experimental Set up}

Freshly harvested, soybean samples of three different cultivars ES5650, ES5507, and ES5542 at initial MC of 10\%, 13\%, and 16\% were obtained from Eagleseed Company in Jonesboro Arkansas. The samples were then manually cleaned to remove dirt and broken seed. The cleaned soybeans were immediately used for germination and vigor tests following procedures of the International Seed Testing Association (ISTA, 2015). The MCs of the samples reported in this study were determined using the AM 5200 Grain Moisture Tester (PERTEN Instruments, Hägersten, Sweden), which is calibrated using the American Society of Biological 
Engineers (ASABE) standard (Jindal and Siebenmorgen, 1987). The experimental setup consisted of three test containers located within a large, insulated unit called a Parameter Generation \& Control (PG\&C). Air temperature and RH conditions were controlled using this equipment. The setup is used to maintain a constant RH throughout the experimental run. Temperature and RH inside the PG\&C was monitored continuously using a data logger. The storage environments simulate those experienced by soybeans in natural air-drying scenario in Arkansas. For tests, the equipment was set to maintain soybean $\mathrm{MC}$ at $10 \%, 13 \%$, and $16 \%$ wet basis; at four levels of temperatures $15^{\circ} \mathrm{C}, 25^{\circ} \mathrm{C}, 30^{\circ} \mathrm{C}$, and $40^{\circ} \mathrm{C}$. Seed sample weighing $600 \mathrm{~g}$ was placed inside the PG\&C for 60 days. During the study, $100 \mathrm{~g}$ samples were taken at day 5, $10,20,30,40$, and 60 to conduct germination and electrical conductivity tests. In addition, samples taken at these intervals were also used to conduct tests of oil quality, such as total oil content, free fatty acids, and peroxide value. Oil quality related tests were conducted at Whitbeck labs in Springdale, Arkansas.

\section{Germination Test}

Standard methods for determination of germination were followed (ISTA, 2015). A filter paper was used as the germination medium. The seeds were soaked in distilled water following the method described in ISTA procedure (ISTA, 2015). The germinator (Conviron G 2100 Germination Chamber, Winnipeg, Manitoba, Canada) (Fig. 2.1) was set at $25^{\circ} \mathrm{C}$ and $8 \mathrm{~h}$ light regime of 1250 lux (simulation of daylight) and air RH of 97\%. A sample of 100 seeds were selected and placed inside the germinator for 7 days. Inside the germinator, the distilled water

and the temperature enable seed germination to occur (Dragicevic et al., 2013). The germination was calculated as number of seeds that germinated out of the total seeds tested. 


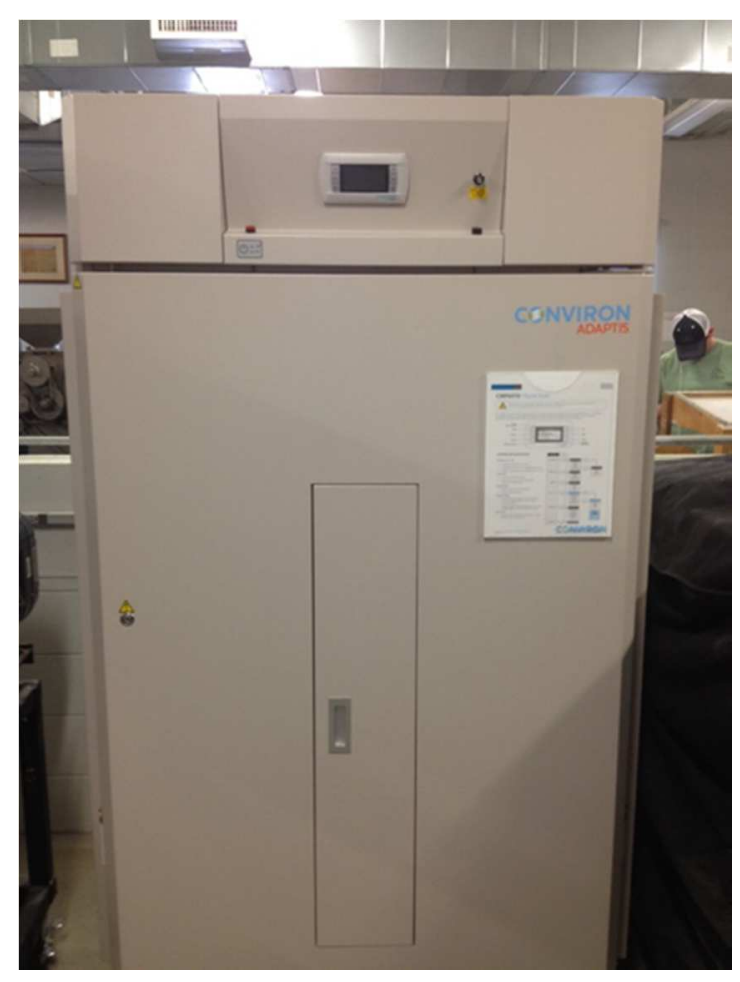

Figure 2.1: The G1000 Germinator was set at $25^{\circ} \mathrm{C}$ and $8 \mathrm{~h}$ light regime of 1250 lux (simulation of daylight) and air relative humidity of $97 \%$ to carry out the standard germination tests.

\section{Electrical Conductivity Test}

The electrical conductivity test was determined by selecting 100 seed samples from the conditioned samples. Then, seeds were soaked in $75 \mathrm{~mL}$ deionized water at $25^{\circ} \mathrm{C}$ for $24 \mathrm{~h}$. After this period, EC readings were taken by using conductivity meter (figure 2.2); the results were expressed in $\mu \mathrm{S} \mathrm{cm-1}$ g-1 of seeds (Wain-Tassi et al., 2012).

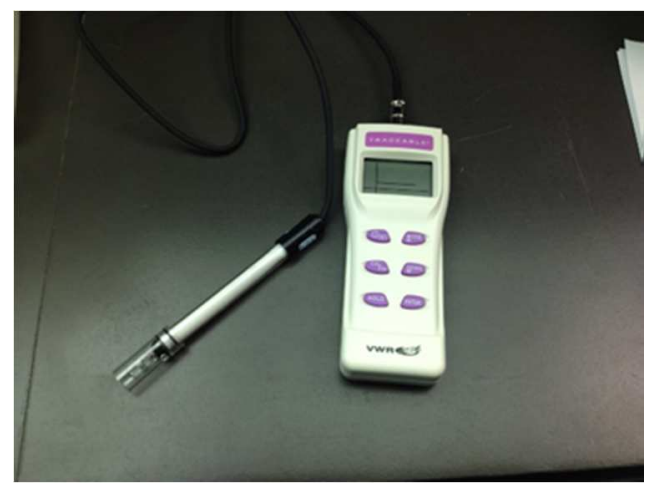

Figure 2.2: The electrical conductivity meter. 


\section{Oil Quality Tests}

Peroxide values (PV) of the photoisomerized samples were measured in duplicate according to an AOCS method. (AOCS Cd 8-53).

Free fatty acid concentration (FFA) of the photoisomerized samples were measured in duplicate according to an AOCS method. (AOCS Ca 5a-40).

\section{Statistical Analysis}

All experiments were conducted in triplicates. The results are presented in relevant sections as mean values and standard deviation. Analysis of variance, and Student's t test (least significant difference test) was performed with a statistical software (JMP version 12.0.0, SAS Institute). In addition, a pairwise t-test using least square mean with Tukey multiple comparison test was performed for each effect, and the interactions and significant differences reported. All tests were considered to be significantly different when $\mathrm{p} \leq 0.05$.

\section{Results \& Discussion}

\section{Germination Rate}

In accordance to the results of the analysis of variance $(p<0.05)$, there was a significant difference in the percentage of germination due to the triple interaction between $\mathrm{MC}$, temperature and storage period. In general, decreased germination occurred during the storage, regardless of $\mathrm{MC}$ and temperature (Figures. 2.1, 2.2, 2.3). At the temperature of $25^{\circ} \mathrm{C}$, the reduction of the germination potential was more accentuated when the soybean grains were stored with $\mathrm{MC}$ of $16 \%$. However, for the temperatures $30^{\circ} \mathrm{C}$ and $40^{\circ} \mathrm{C}$, the reduction of germination potential took place independently of the MC. It is clear, however, that the reduction 
was more accentuated as the MC of the grains increased. Dorworth and Christensen (1968) obtained similar results when they stored soybean at four MCs and four temperatures, even though they had not controlled the RH during the storage. According to Burris (1980), the fast deterioration of the soybean during the period of storage is influenced by the MC and temperature. The qualitative deterioration of soybean stored with initial moisture contents between $9.8 \%$ and $13.8 \%$ in tropical conditions $\left(30^{\circ} \mathrm{C}\right.$ and $\left.82 \% \mathrm{RH}\right)$ was simulated by Locher and Bucheli (1998). These authors verified a more pronounced reduction in the percentage of germination between 5 and 9 months of storage, and this was more accentuated in grains with a higher initial MC. 
Storage duration (day)
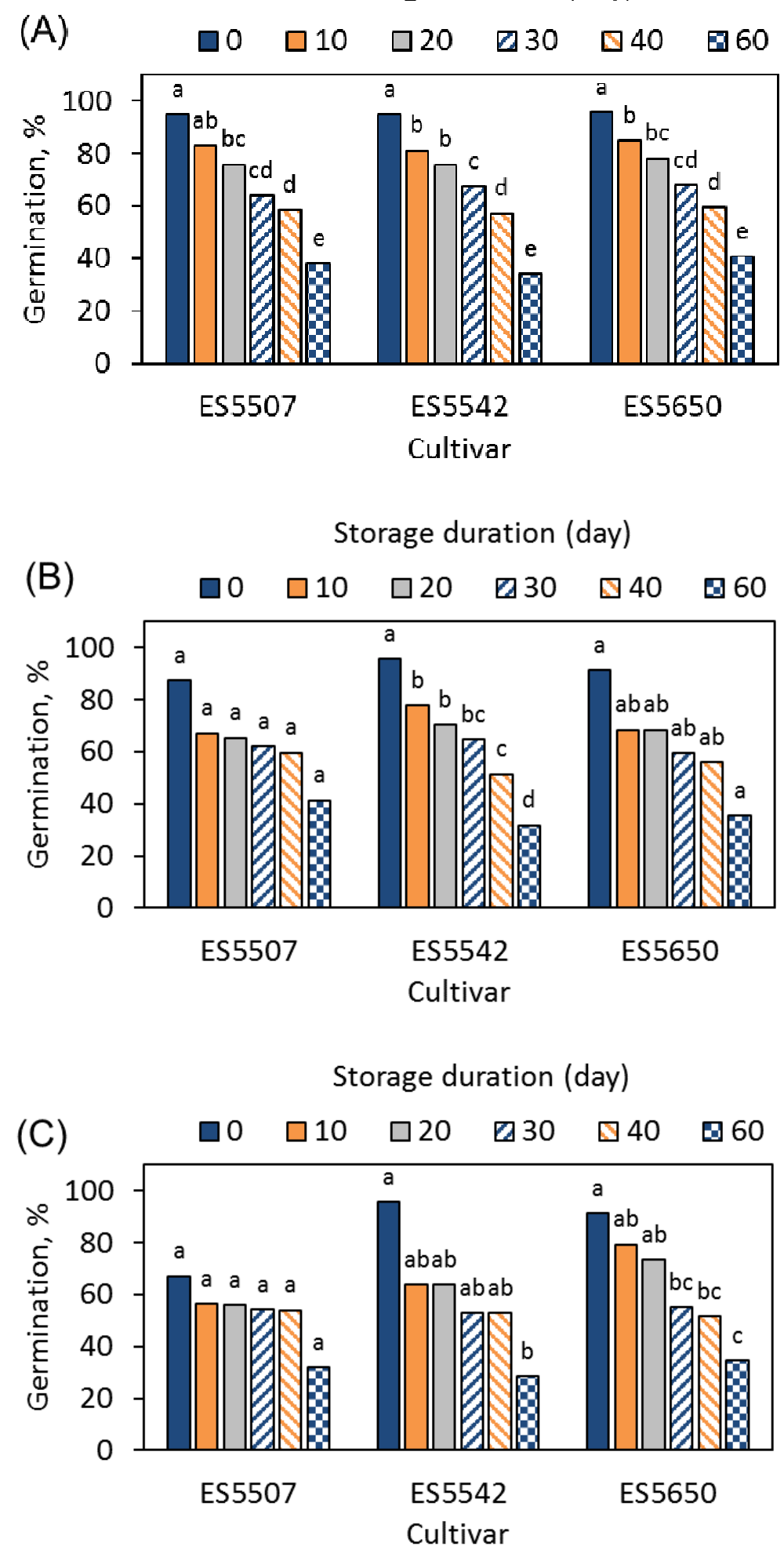

Fig. 2.1. Germination results for soybeans of an initial moisture content of $16 \%$ stored at (a) $25^{\circ} \mathrm{C}$, (b) $30^{\circ} \mathrm{C}$ and (c) $40^{\circ} \mathrm{C}$. 

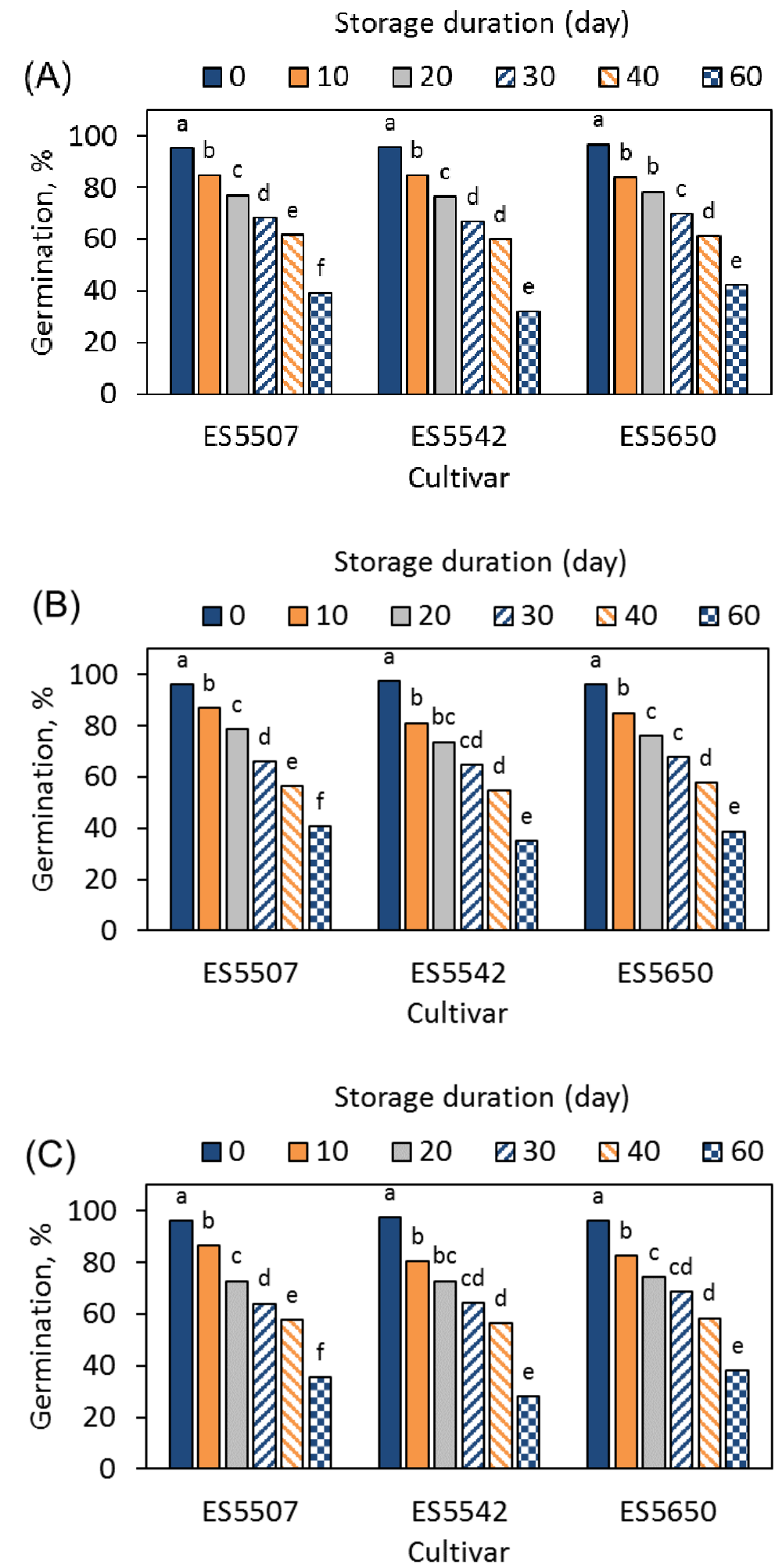

Fig. 2.2. Germination results for soybeans of an initial moisture content of $13 \%$ stored at (a) $25^{\circ} \mathrm{C}$, (b) $30^{\circ} \mathrm{C}$ and (c) $40^{\circ} \mathrm{C}$. 

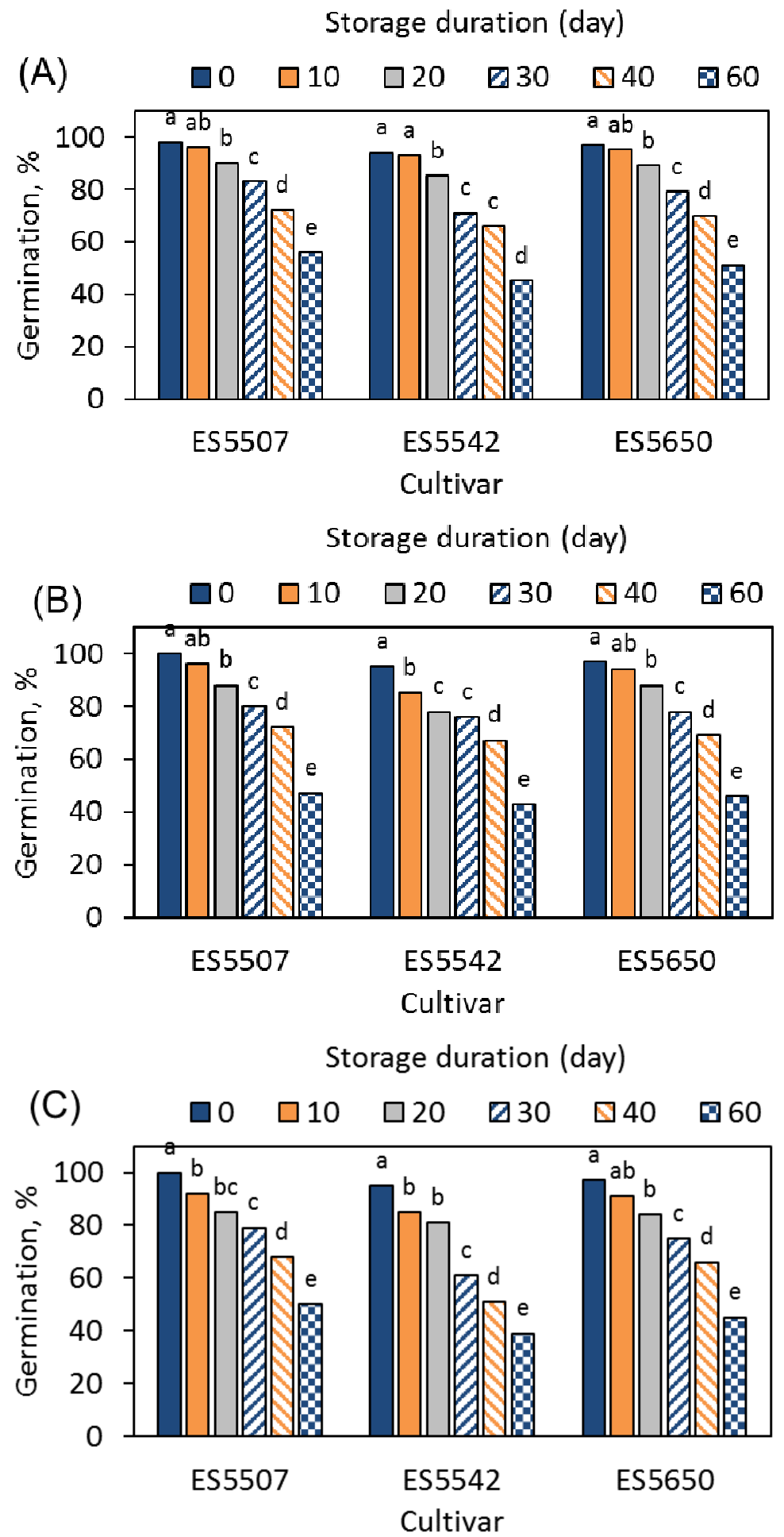

Fig. 2.3. Germination results for soybeans of an initial moisture content of $10 \%$ stored at (a) $25^{\circ} \mathrm{C}$, (b) $30^{\circ} \mathrm{C}$ and (c) $40^{\circ} \mathrm{C}$. 


\section{Electrical Conductivity}

The analysis of variance $(\mathrm{p}<0.05)$ indicated that there was significant variation of electrical conductivity of the solution that contained the soybean due to the interaction of $\mathrm{MC}$, temperature, and storage period. It can be seen that soybeans stored at all temperatures and MCs show an increase of the electrical conductivity and consequent reduction of their physiological quality, (Fig. 2.4, 2.5, 2.6). In agreement with Heslehurst (1988), readings taken of the electrical conductivity of the solution that contains the grains can be used to evaluate their vigor, because the conductivity is related with the amount of ions leached into the solution, which in turn is directly associated with the integrity of the cellular membranes; badly structured membranes and damaged cells are usually associated with the process of seed deterioration and reduced vigor. The loss of germination and vigor of old seeds is positively correlated with the electrolytic leaching, which increases with the decrease of the phospholipid content of the membrane (Lin, 1990). The smallest values, corresponding to the smallest exudate liberation, indicate high physiological potential (larger vigor), which indicates a smaller disorder intensity in the cell membrane systems (Vieira et al., 2002). The increase of electrical conductivity was more expressive as the temperature and $\mathrm{MC}$ of the grains increased. Seeds stored at $40^{\circ} \mathrm{C}$ showed increased electrical conductivity of grains during the storage period, regardless of the grain MC. Krittigamas et al. (2001) used the electrical conductivity as a parameter in the determination of vigor in stored soybean. The authors observed a significant increase of this parameter and consequent loss of vigor in the grains after 180 days. 

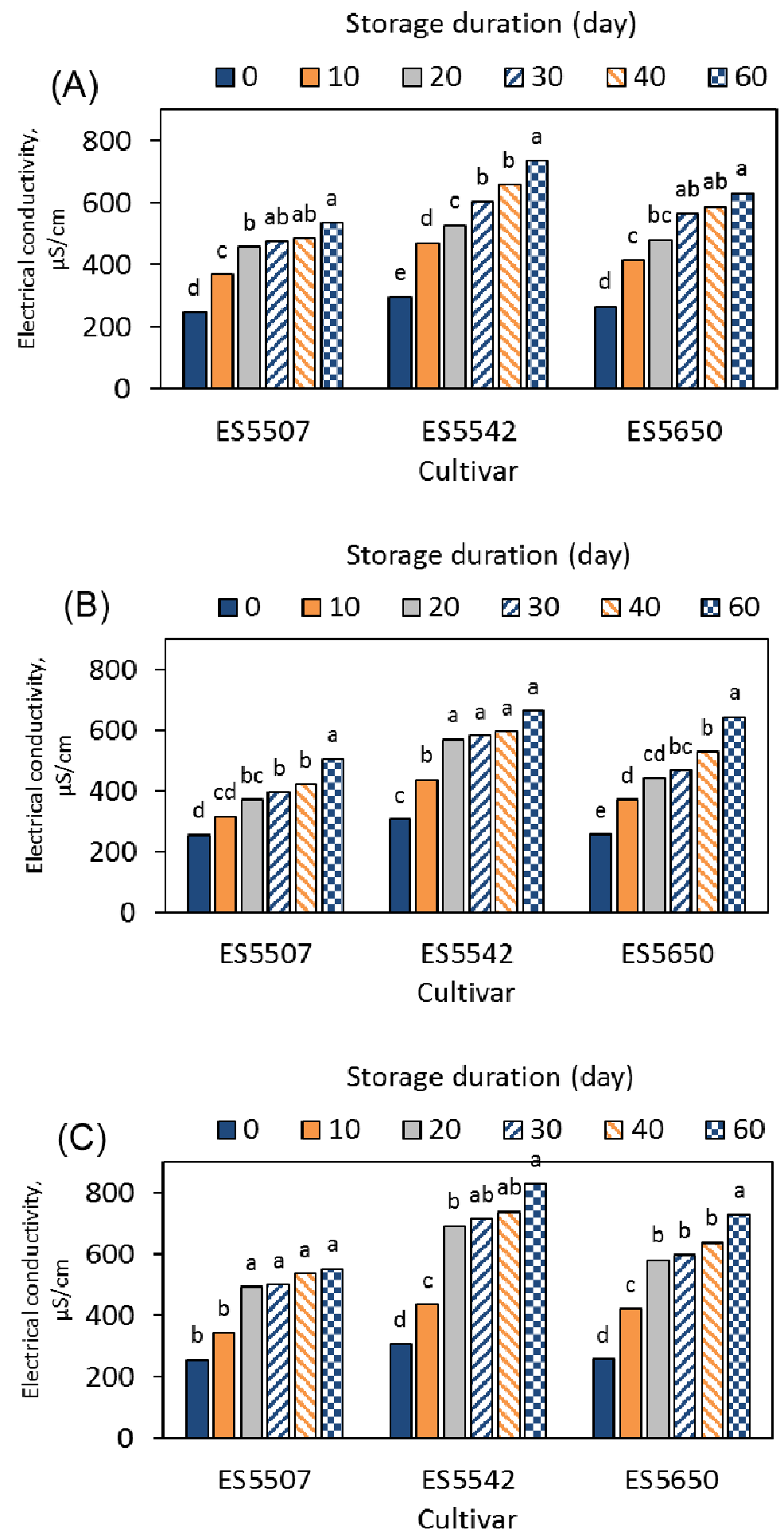

Fig. 2.4. Electrical conductivity results for soybeans of an initial moisture content of $16 \%$ stored at (a) $25^{\circ} \mathrm{C}$, (b) $30^{\circ} \mathrm{C}$ and (c) $40^{\circ} \mathrm{C}$. 


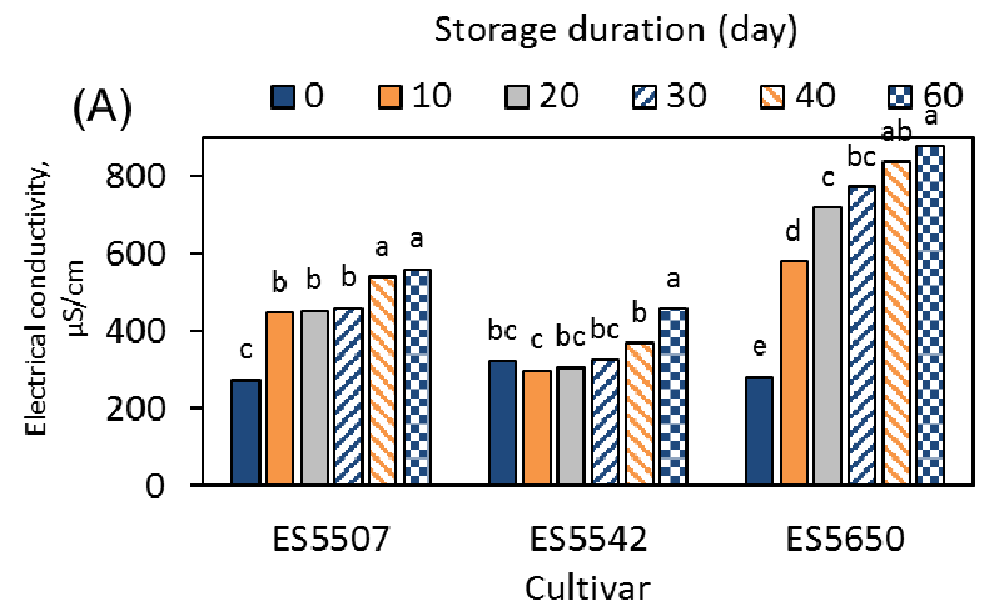

Storage duration (day)

(B) $\square 0 \quad \square 10 \quad \square 20 \quad \square 30 \quad \square 40 \quad \square 60$

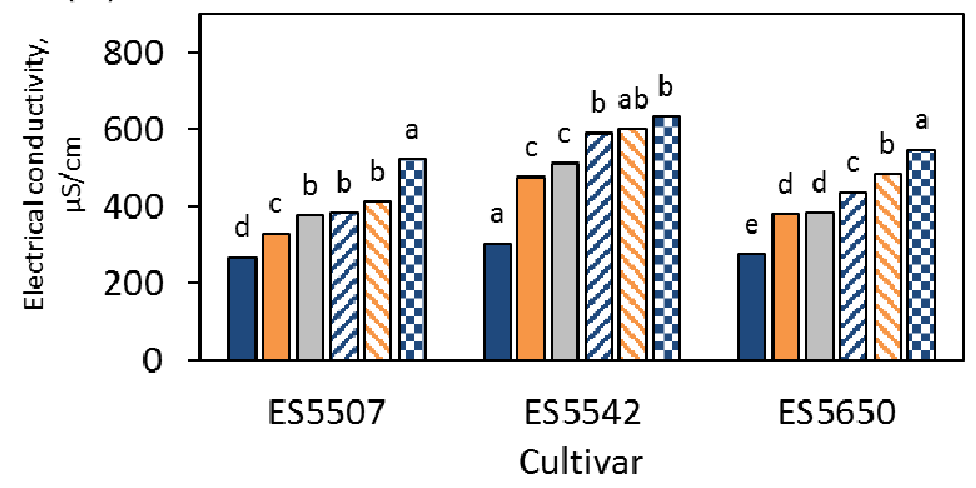

Storage duration (day)

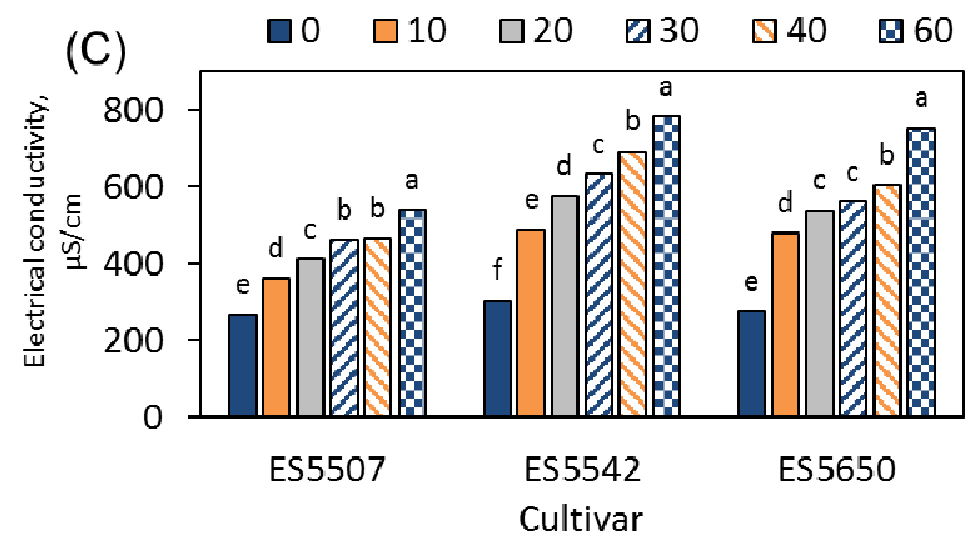

Fig. 2.5. Electrical conductivity results for soybeans of an initial moisture content of $13 \%$ stored at (a) $25^{\circ} \mathrm{C}$, (b) $30^{\circ} \mathrm{C}$ and (c) $40^{\circ} \mathrm{C}$. 
Storage duration (day)
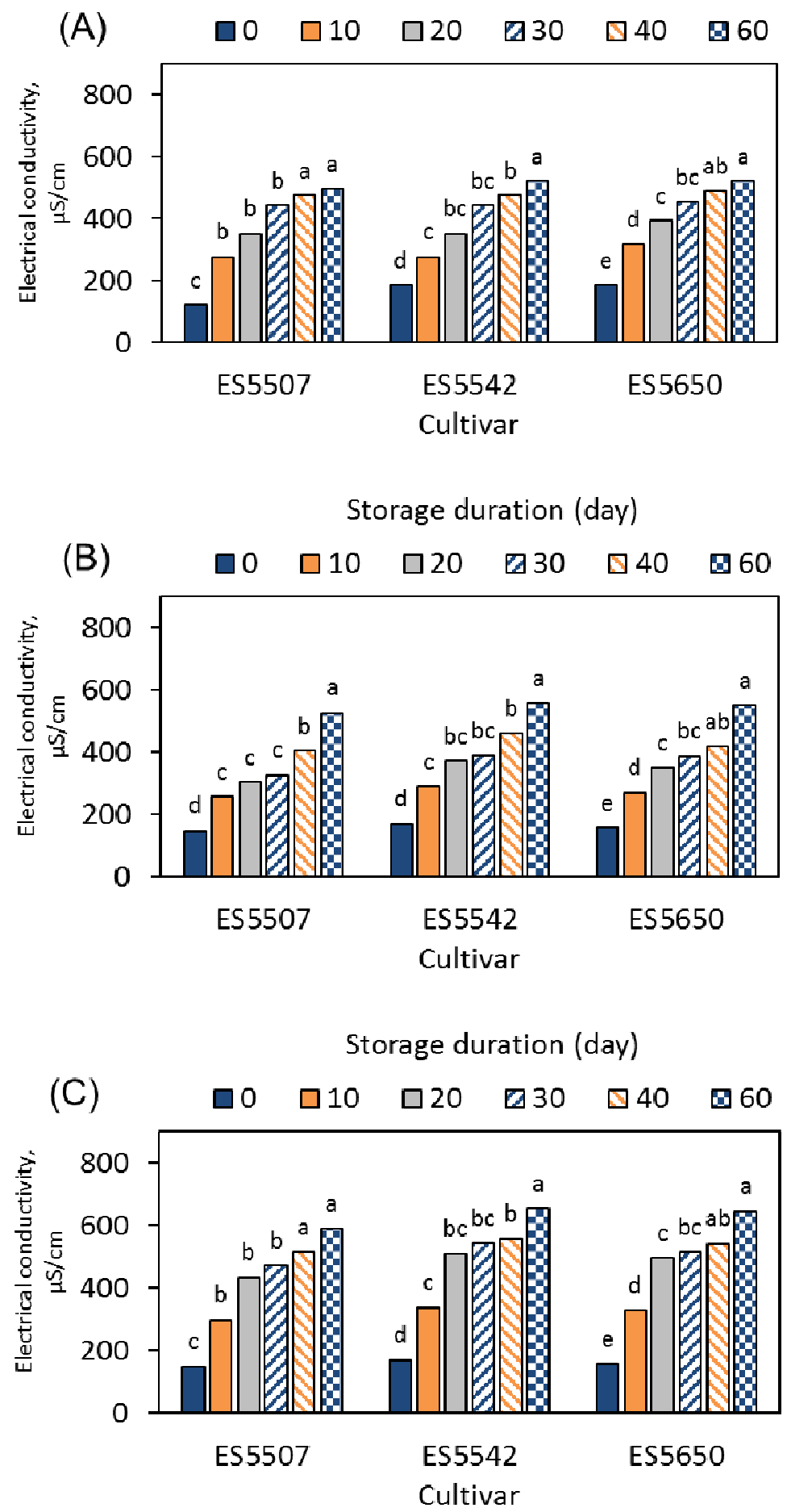

Fig. 2.6. Electrical conductivity results for soybeans of an initial moisture content of $10 \%$ stored at (a) $25^{\circ} \mathrm{C}$, (b) $30^{\circ} \mathrm{C}$ and (c) $40^{\circ} \mathrm{C}$. 


\section{Free Fatty Acid and Peroxide Value}

There was a significant difference $(p<0.05)$ in the FFA content of oil extracted from the stored soybeans with a significant interaction observed between temperature and storage period. The FFA content of oil from grain stored at $15^{\circ} \mathrm{C}$ to $25^{\circ} \mathrm{C}$ did not change significantly during the entire storage period. However, it increased significantly, if storage was done at $30^{\circ} \mathrm{C}$ or $40^{\circ} \mathrm{C}$ (Fig 2.7).

The FFA content of oil increases due to lipid hydrolysis by lipases, peroxidases and phospholipases enzymes present in grain tissues or produced by the associated microorganisms (Zadernowski et al., 1999). There are several reports relating FFA increase under storage conditions. Yanagi et al. (1985) reported the influence of storage duration on FFA content of oil from soybeans with $13.7 \%$ or $9.3 \% \mathrm{MC}$ stored at $30^{\circ} \mathrm{C}$ and $80 \% \mathrm{RH}$. Frankel et al. (1987) also reported the changes in FFA content of oil from soybeans stored at different MC. The grains stored with $13 \%$ MC showed less FFA increase compared to those stored with $16 \%$ or $20 \%$ MC. While the FFA content of oil from soybeans stored at $13 \% \mathrm{MC}$ increased from $0.2 \%$ to $1.25 \%$ after 49 -day storage, that of grains with $16 \%$ or $20 \%$ MC increased from $0.5 \%$ to $2.0 \%$ after 27 days, and from $0.6 \%$ to $2.3 \%$ after 28 days, respectively. Narayan et al. (1988) also reported temporal FFA increase in soybeans stored under ambient conditions, from $0.69 \%$ to $9.85 \%$, after 58-month storage. According to Dhingra et al. (1998), the FFA content of oil extracted from soybean increased significantly due to the interaction between MC and storage period.

The oil peroxide index differed significantly $(\mathrm{p}<0.05)$ among samples due to the interaction between temperature and storage period. Increasing storage periods from 40 and 60 days 
increased peroxide number by 12.61 and $30.27 \%$, respectively compared with before storage treatment (Figure 2.8). Decrease of seed quality is connected with biochemical changes in seeds of oil crops. These seeds had a rapid deterioration due to autoxidation of lipids and the increase of the content of free fatty acids during storage period (Figures 2.7 and 2.8). The longer seeds storage period increases intensity of seeds ageing.

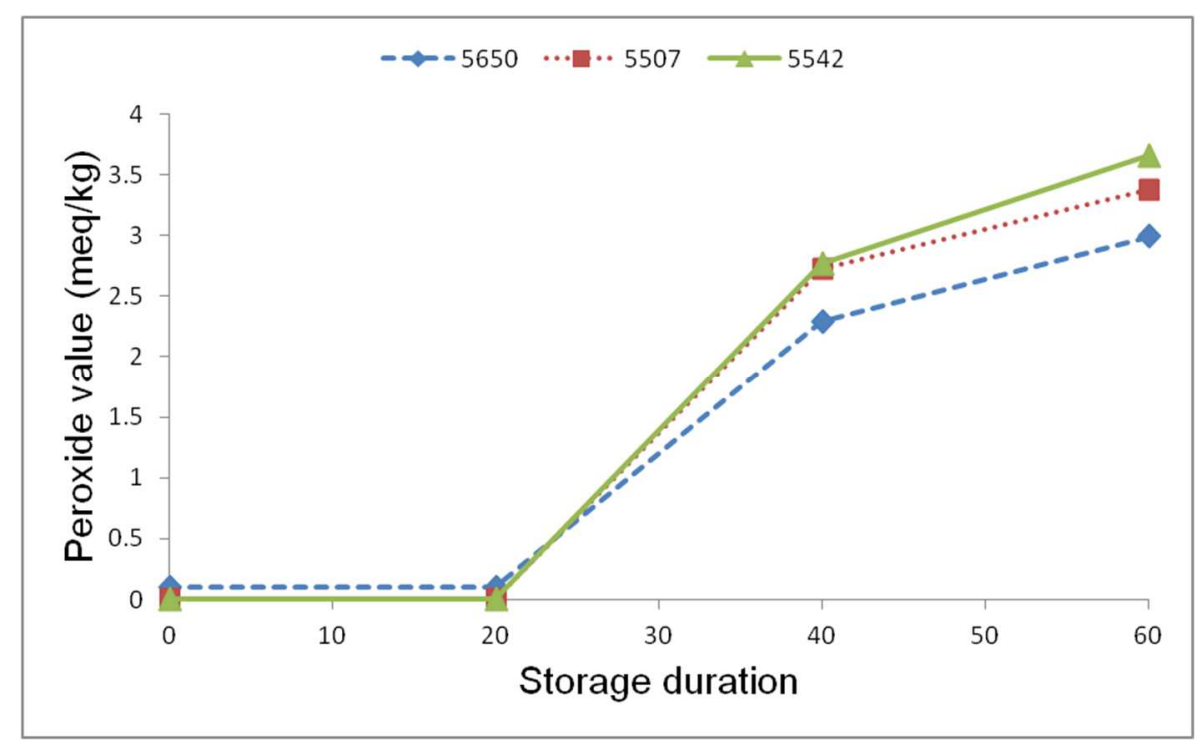

Fig. 2.7. Change in peroxide value over a 60 day storage duration for soybean cultivars ES5650, ES5507, and ES5542. Experiment was conducted with seeds at an initial moisture content of $10 \%$ and a storage temperature of $40^{\circ} \mathrm{C}$. 


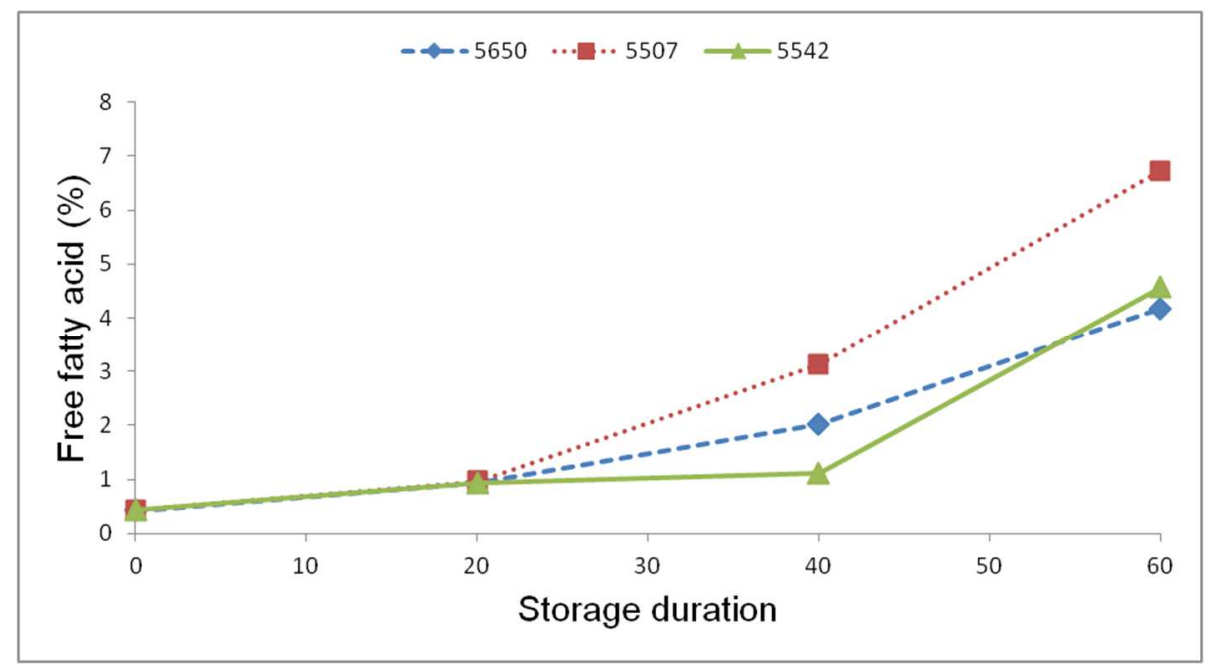

Fig. 2.8. Change in free fatty acid concentration over a 60 day storage duration for soybean cultivars ES5650, ES5507, and ES5542. Experiment was conducted with seeds at an initial moisture content of $10 \%$ and a storage temperature of $40^{\circ} \mathrm{C}$.

\section{E. Conclusions}

The goal of this research study was to determine the effects of seed remaining at MC and temperature ranges encountered during in-bin drying and storage, for certain durations, on germination rates, vigor of the seed, and measures of oil quality such as free fatty acids and peroxide value. The following conclusions were drawn: soybean storage is not recommended in the following combinations of $\mathrm{MC}$ and temperature: $10 \%$ at $40{ }^{\circ} \mathrm{C} ; 13 \%$ at 30 and $40{ }^{\circ} \mathrm{C}$; and $16 \%$ at $25^{\circ} \mathrm{C}, 30^{\circ} \mathrm{C}$ and $40^{\circ} \mathrm{C}$. The results suggest that soybean seed membranes also stabilize at low temperatures, since no significant increase in the electrical conductivity over time was observed. The stored seeds revealed a decline on their physiological quality during storage ( 0 to 60 days) as detected by the germination and electrical conductivity tests at all the temperatures studied. At an IMC of $10 \%$ and a storage temperature of $40^{\circ} \mathrm{C}$, peroxide value and FFA concentration increased as storage duration increased, indicating a decline in overall oil quality. 
The analysis and the interpretation of the results obtained relating to the study allowed the following conclusions: For soybean commercialization at the basic standard level, it is possible to store soybeans for 60 days with moisture content of up to $13 \%$ at $20^{\circ} \mathrm{C}$ and $30^{\circ} \mathrm{C}$. At $40^{\circ} \mathrm{C}$, only the grains with $\mathrm{MC}$ of $10 \%$ can be stored for 60 days.

\section{F. References}

Alencar, E. R. d., L. R. D. Faroni, L. A. Peternelli, M. T. C. d. Silva, and A. R. Costa. (2010). Influence of Soybean Storage Conditions on Crude Oil Quality. Revista Brasileira de Engenharia Agrícola e Ambiental 14(3), 303-308.

Andric, L., T. Teklic, M. Vrataric, A. Sudaric, and V. Duvnjak. (2007). Soybean Seed Vigor and Field Emergence Under Influence of Cultivar, Seed Age and Planting Date. Cereal Research Communications 35(2), 177-180.

Bhattacharya, K. and Raha, S. (2002). Deteriorative Changes of Maize, Groundnut and Soybean Seeds by Fungi in Storage. Mycopathologia, 155 (3), 135-141.

Calero, E., S. H. West, and K. Hinson. (1981). Water Absorption of Soybean Seeds and Associated Causal Factors. Crop Science 21(6).

Colete, J. C. F., R. D. Vieira, and A. S. Dutra. (2004). Electrical Conductivity and Soybean Seedling Emergence. Scientia Agricola 61(4), 386-391.

De Alencar, E., L. Faroni, A. de Lacerda Filho, L. Ferreira, and M. Meneghitti. (2006). Influence of Different Storage Conditions on Soybean Grain Quality. In 9th International Working Conference on Stored Product Protection.

De Alencar, E. R., D. Lêda Rita, and A. Faroni. (2011). Storage of Soybeans and Its Effects on Quality of Soybean Sub-Products. 9th International Working Conference on Stored Product Protection.

Dhingra, O.D., Jham, G. \& Napoleão, I.T.. (1998). Ergosterol Accumulation and Oil Quality Changes in Stored Soybean Invaded by Aspergillus ruber (A. glaucus group), Mycopathologia 143, 85-91.

Dornbos, D.L. \& Mullen, R.E., (1992). Soybean Seed Protein and Oil Contents and Fatty Acid Composition Adjustments by Drought and Temperature. Journal of the American Oil Chemists Society. Volume 69(3), 228-231 
Dragicevic, V., M. Spasic, M. Simic, Z. Dumanovic, and B. Nikolic. (2013). Stimulative Influence of Germination and Growth of Maize Seedlings Originating from Aged Seeds by 2,4-D Potencies. Homeopathy 102(3), 179-186.

Frankel, E., A. Nash, and J. Snyder. (1987). A Methodology Study to Evaluate Quality of Soybeans Stored at Different Moisture Levels. Journal of the American Oil Chemists' Society 64(7), 987-992.

ISTA. (2015). Chapter 5: The Germination Test. International Rules for Seed Testing 2015(1), 5-1- 5-56.

Hepperly, P. R., and J. B. Sinclair. (1978). Quality Losses in Phomopsis-Infected Soybean Seeds. Phytopathology 68, 1684-1687.

Kandil, A., A. Sharief, and M. Sheteiwy. (2013). Effect of Seed Storage Periods, Conditions and Materials on Seed Quality of Some Soybean Cultivars. International Journal of Agriculture Sciences 5(1), 339 .

Khalilaqdam, N., A. Soltani, N. Latifi, and F. G. Far. (2012). Quantitative Response of the Longevity of Soybean Seed Under Controlled Conditions. American-Eurasian journal of agriculture and environments sciences 12(2), 224-230.

Kpoghomou, B. K., V. T. Sapra, and C. A. Beyl. (1990). Screening for Drought Tolerance: Soybean Germination and its Relationship to Seedling Responses. Journal of Agronomy and Crop Science 164(3), 153-159.

Locher, R., and P. Bucheli. (1998). Comparison of Soluble Sugar Degradation in Soybean Seed Under Simulated Tropical Storage Conditions. Crop Science 38(5), 1229-1235.

Ochiai Yanagi, S., M. A. Galeazzi, and K. Saio. (1985). Properties of Soybean in Model Storage Studies. Agricultural and Biological Chemistry, 49(2), 525-528.

Panobianco, M., and R. D. Vieira. (2007). Eletrical Conductivity and Deterioration of Soybean Seeds Exposed to Different Storage Conditions. Revista Brasileira de Sementes 29, 97-105.

Vieira, R. D., D. Tekrony, D. Egli, and M. Rucker. (2001). Electrical Conductivity of Soybean Seeds After Storage in Several Environments. Seed Science and Technology 29(3), 599-608.

Vieira, R. D., D. M. TeKrony, D. B. Egli, W. P. Bruenning, and M. Panobianco. (2008).

Temperature During Soybean Seed Storage and the Amount of Electrolytes of Soaked Seeds Solution. Scientia Agricola 65, 496-501.

Wain-Tassi, A. L., J. F. d. Santos, R. d. C. Panizzi, and R. D. Vieira. (2012). Seed-Borne Pathogens and Electrical Conductivity of Soybean Seeds. Scientia Agricola 69(1), 19-25. 
Wolf, R.B., Cavins, J.F., and Kleiman, R.. (1982). Effect of Temperature on Soybean Seed Constituents: Oil, Protein, Moisture, Fatty Acids, Amino Acids and Sugars. Journal of the American Oil Chemists' Society. Volume 59(5), 230-232 


\section{Conclusion}

In summary, this study finds the modified Halsey and Oswin equations as the most appropriate equations for describing soybean EMC/ERH sorption isotherms based on their ability to fit multiple data sets. The modified GAB equation and the modified Chung-Pfost equation are less suitable for describing the EMC/ERH sorption isotherms of soybean seed. The fitted equations presented here for adsorption and desorption with the combined data provide a useful basis for future work on drying and storage of soybean seed.

The following conclusions were drawn in regard to seed storage: soybean storage is not recommended in the following combinations of $\mathrm{MC}$ and temperature: $10 \%$ at $40{ }^{\circ} \mathrm{C} ; 13 \%$ at 30 and $40{ }^{\circ} \mathrm{C}$; and $16 \%$ at $25^{\circ} \mathrm{C}, 30^{\circ} \mathrm{C}$ and $40^{\circ} \mathrm{C}$. The results suggest that soybean seed membranes also stabilize at low temperatures, since no significant increase in the electrical conductivity over time was observed. The stored seeds revealed a decline on their physiological quality during storage ( 0 to 60 days) as detected by the germination and electrical conductivity tests at all the temperatures studied. At an IMC of $10 \%$ and a storage temperature of $40^{\circ} \mathrm{C}$, peroxide value and FFA concentration increased as storage duration increased, indicating a decline in overall oil quality.

The analysis and the interpretation of the results obtained relating to the study allowed the following conclusions: For soybean commercialization at the basic standard level, it is possible to store soybeans for 60 days with moisture content of up to $13 \%$ at $20^{\circ} \mathrm{C}$ and $30^{\circ} \mathrm{C}$. At $40^{\circ} \mathrm{C}$, only the grains with MC of $10 \%$ can be stored for 60 days. 